\title{
Dose Potential of Sludge Contaminated and/or TRU Contaminated Waste in B-25s for Tornado and Straight Wind Events
}

by

c. I. Aponte

Westinghouse Savannah River Company

Savannah River Site

Aiken, South Carolina 29808

E. T. Ketusky

SAIC

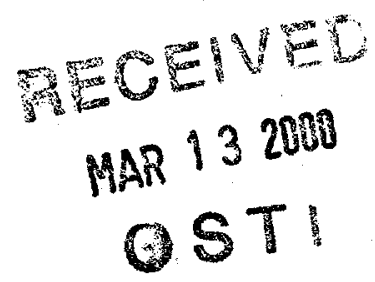

DOE Contract No. DE-AC09-96SR18500

This paper was prepared in connection with work done under the above contract number with the U.S. Department of Energy. By acceptance of this paper, the publisher and/or recipient acknowledges the U.S. Government's right to retain a nonexclusive, royalty-free license in and to any copyright covering this paper, along with the right to reproduce and to authorize others to reproduce all or part of the copyrighted paper. 


\section{DISCLAIMER}

This report was prepared as an account of work sponsored by an agency of the United States Government. Neither the United States Government nor any agency thereof, nor any of their employees, makes any warranty, express or implied, or assumes any legal liability or responsibility for the accuracy, completeness, or usefulness of any information, apparatus, product or process disclosed, or represents that its use would not infringe privately owned rights. Reference herein to any specific commercial product, process or service by trade name, trademark, manufacturer, or otherwise does not necessarily constitute or imply its endorsement, recommendation, or favoring by the United States Government or any agency thereof. The views and opinions of authors expressed herein do not necessarily state or reflect those of the United States Government or any agency thereof.

This report has been reproduced directly from the best available copy.

Available for sale to the public, in paper, from: U.S. Department of Commerce, National Technical Information Service, 5285 Port Royal Road, Springfield, VA 22161

phone: (800) 553-6847

fax: (703) 605-6900

email: orders@ntis.fedworld.gov

online ordering: http://www.ntis.gov/ordering.htm

Available electronically at http://www.doe.gov/bridge

Available for a processing fee to U.S. Department of Energy and its contractors, in paper, from: U.S. Department of Energy, Office of Scientific and Technical Information, P.O. Box 62, Oak Ridge, TN 37831-0062

phone: (865)576-8401

fax: (865)576-5728

email: reports@adonis.osti.gov 


\section{DISCLAIMER}

Portions of this document may be illegible in electronic image products. Images are produced from the best available original document. 
Duplicate Original

Concentration, Storage and Transfer Engineering Concentration, Storage and Transfer Engineering Support
RECORDS ADMINISTRATION

Ro091103
BEST AVAILABLE COPY

Dose Potential of Sludge Contaminated and/or TRU Contaminated Waste in B-25s For Tornado and Straight Wind Events

February 2, 1998

E. T. Ketusky, SAIC for WSRC C. I. Aponte, WSRC
WSRC-TR-98-00050

Revision 0

KEYWORDS:

High Level Waste Sludge. TRU

B-25

Retention:

PERMANENT

CLASSIFICATION:

(xames)Boluet W lister 2/17/98

Date $2 / 12 / 98$

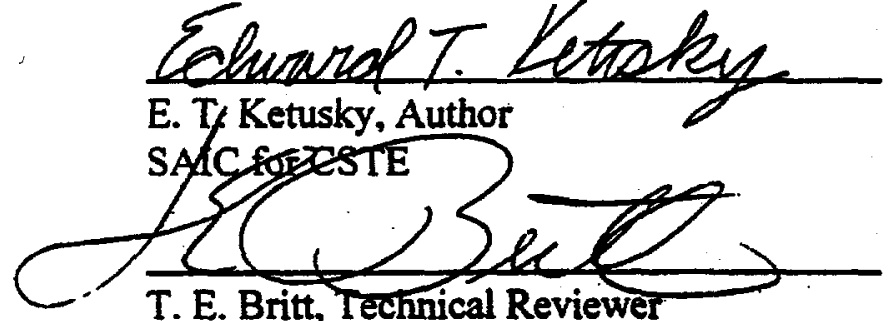

Concentration, Storage and Transfer Engineering

$\frac{\text { Hd } 2 \text { for M.C.chand/s }}{\text { M. C. Chandler, Manager }}$

CSTE Characterization

B. L. Lewis, Manager

CSTE Support

Uflickent ta

T. M. Monahon, Manager CSTE Engineering

BEST AVAILABLE COPY

Date $2 / 13 / 98$

$2 / 13 / 187$

Date _2/13/98: 
Table of Contents

1.0 INTRODUCTION

$$
1902
$$

Page Number $\therefore$ . .1

2.0 SUMMARY

3.0 ISOTOPES

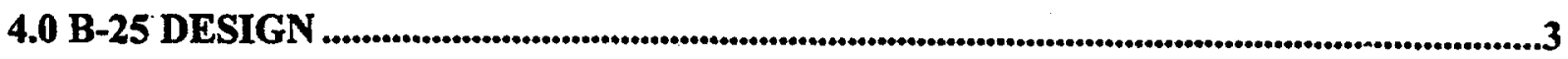

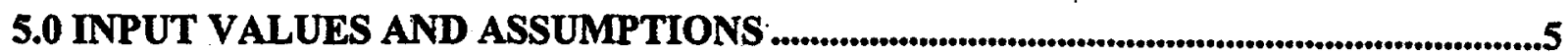

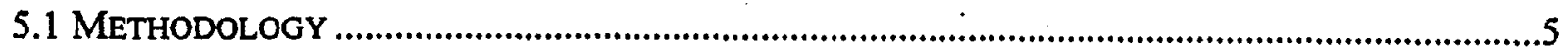

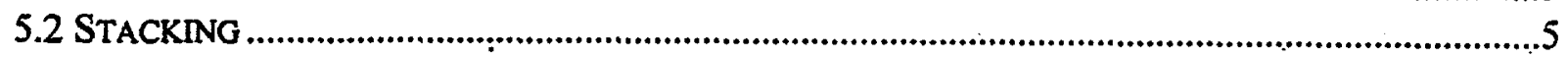

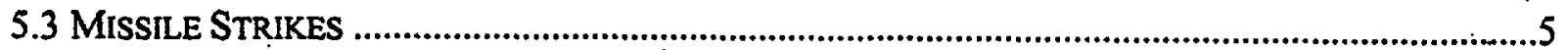

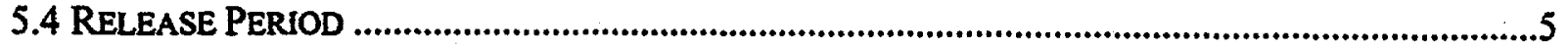

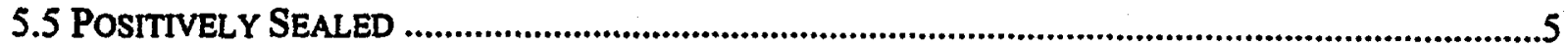

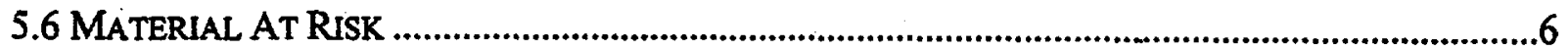

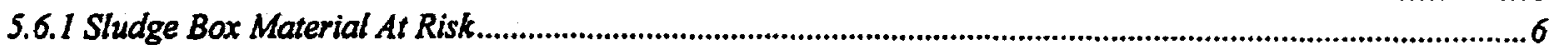

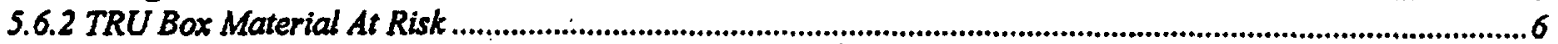

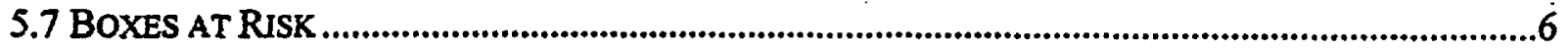

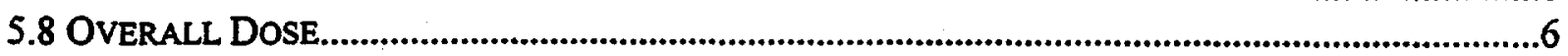

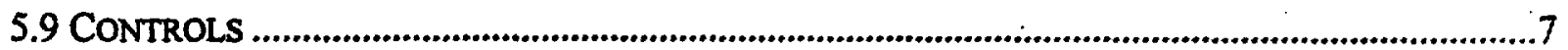

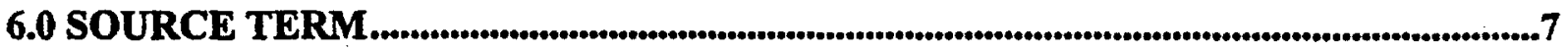

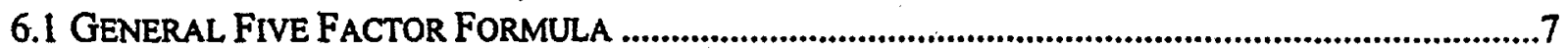

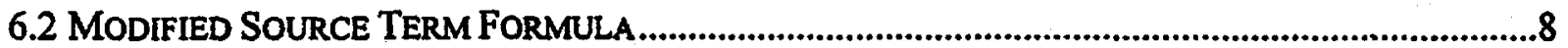

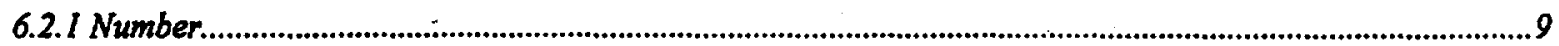

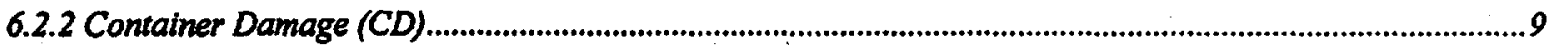

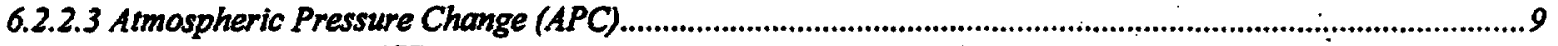

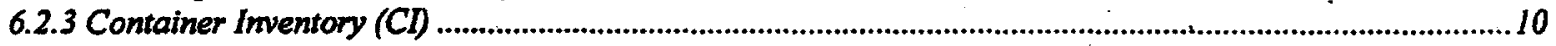

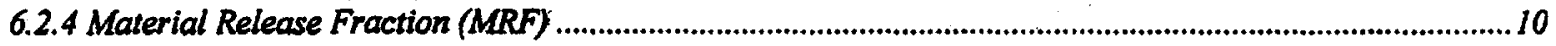

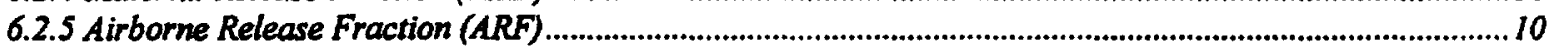

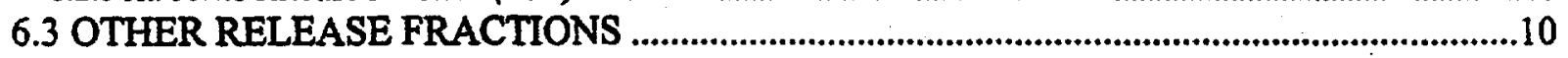

7.0 DISPERSION

8.0 WEIGHT

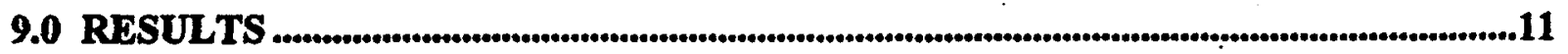

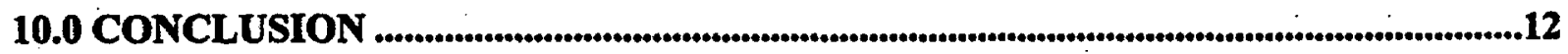

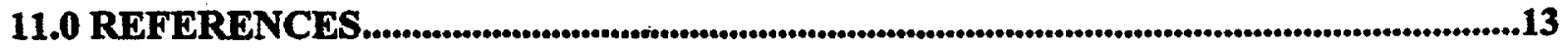


WSRC-TR-98-00050.

Revision 0

February 10, 1998

Page ii of 55

Attachments

Page Number

Attachment I - Impact of Supernate Contaminated Boxes............................................................................... If

Attachment 2 - Hazard Classification Table (Solid Waste) .................................................................... 15

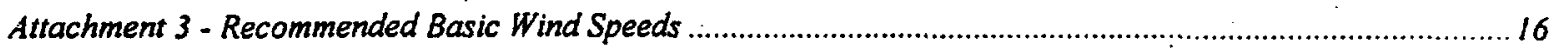

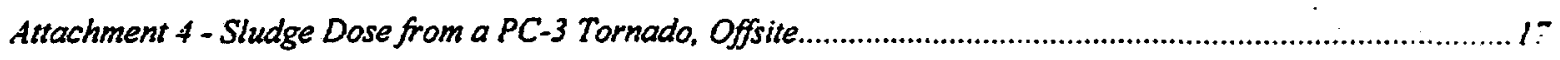

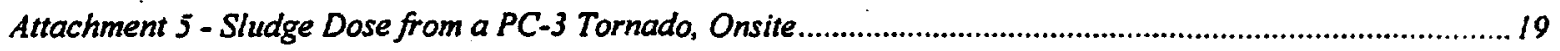

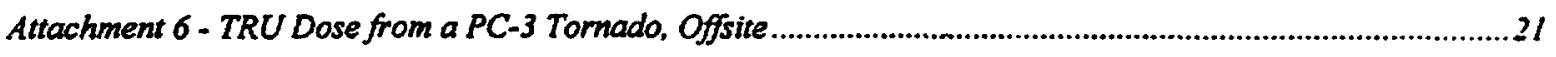

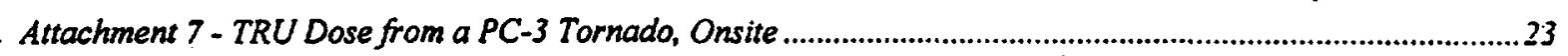

Attachment $8 \mathrm{~A}$ and $8 B$ - TRU Curies Allowed for Offsite Limit/Onsite Guideline ...........................................25

Attachment 9 - Procurement Specification for Low Level Waste Boxes (U)...............................................26

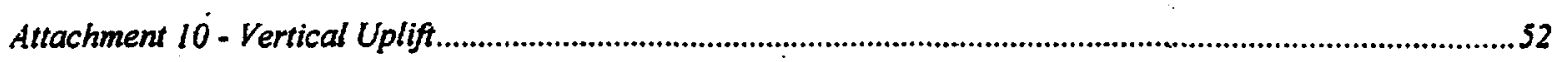

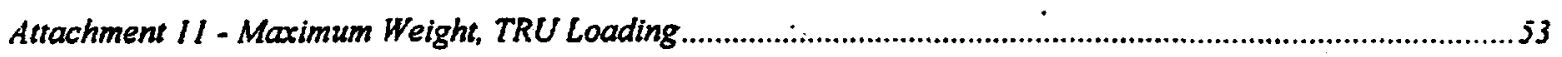


WSRC-TR-98-00050

Revision 0

February 10, 1998

Page 1 of 55

\subsection{INTRODUCTION}

$\mathrm{F}$ and $\mathrm{H}$ Tank Farms generate supernate and sludge contaminated Low Level Waste. The waste is collected, characterized, and packaged for disposal. Before the waste can be disposed of. however, it must be properly characterized. Since the radionuclide distribution in typical supernate is well known, its characterization is relatively straight forward and requires minimal effort.

Non-routine waste, including potentially sludge contaminated, requires much more effort to effectively characterize. The radionuclide distribution must be determined. In some cases the waste can be contaminated by various sludge transfers with unique radionuclide distributions. In these cases, the characterization can require an extensive effort. Even after an extensive characterization effort, the container must still be prepared for shipping. Therefore a significant amount of time may elapse from the time the waste is generated until the time of disposal.

During that time it is possible for a tornado or high wind scenario to occur. The purpose of this . report is to determine the effect of a tornado on potential sludge contaminated waste, or Transuranic ${ }^{1}$ (TRU) waste in B-25s, to evaluate the potential impact on F and H Tank Farms, and to help establish a B-25 control program for tomado events. An explicit assessment for high-velocity straight winds (non-tornado high winds) is not performed because the natural phenomena evaluation guidance contained in Section 3.2 of Reference 1 concludes that the overall risks from tornadoes bound corresponding overall risks from straight winds and therefore the tornado results can be conservatively applied to straight winds. Also based on analysis, the source term associated with a Performance Category 3 (PC-3) tornado can also be used to bound a vehicle accident.

Supernate contaminated boxes are not a concern and are not addressed in this report because of the volume of the supernate that would be required to exceed the onsite guideline is about 1200 gallons. According to the High Level Waste Characterization of Low Level Waste Certification Manual (U), WSRC-TR-94-0581, each waste box on average contains significantly less than 1 gallon of waste. Therefore all material at risk associated with the 1,200 boxes would have to be released. This is judged to be incredible. Refer to Attachment 1 .

\subsection{SUMMARY}

The methodology used for analysis was based largely on the methodology used to analyze a tomado in the TRU Waste Pads, as found in the Solid Waste Management Facility, Hazard and Accident Analysis, WSRC-SA-22, and supporting calculations (Ref. 2 and 3).

(1) TRU waste is roughly defined as waste with an activity of greater than 100 nanocuries/g from isotopes with an atomic number greater than that of uranium and having a half life of greater than 20 years. 
WSRC-TR-98-00050

Revision 0

February 10.1998

Page 2 of 55

The Liquid Radioactive Waste Handling Facility (LRWHF) is defined as a Hazard Category 2 facility, as are the TRU Waste Pads (Excerpt from Ref. 2 - Attachment 2). A review of DOE-STD-1020-94 and DOE-STD-1021-94 enabled a PC-3 tornado to be used as. the bounding high wind (tornado) scenario for the TRU waste pads. The Hazard and Accident Analysis for Solid Waste (SW), WSRC-SA-22 (Ref. 2). analyzed the impact of a PC-3 tornado on B-25s at the TRU waste pad. Based on the categorization, the analysis required the use of a tornado of at least $137 \mathrm{mph}$ winds, with an importance factor of 1.0. However, the actual analysis was not completed, but instead the results of an earlier bounding analysis were used. The earlier analysis was performed in accordance with the previous Department of Energy Guidelines entitled, "Design and Evaluation Guidelines for Department of Energy Facilities Subjected to Natural Phenomena Hazards, UCRL-15910" for a high hazard facility. The UCRL-15910 analysis determined the impact from a tornado with the fastest wind speed of $137 \mathrm{mph}$ and a corresponding importance factor of 1.35 (or an equivalent wind speed of approximately $190 \mathrm{mph}$ ). Since the Hazard Categories of both LRWHF and the SW TRU Waste Pads are the same, the methodology used for the SW analysis can be applied to the LRWHF B-25s. (Refer to Attachment 3 - Selected Excerpts of DOESTD-1020-94). Any conservatism which existed in the SW analysis will also exist in the LRWHF analysis.

An important difference in the application of the methodology is that the Solid Waste Authorization Basis, WSRC-SA-22 (Ref. 2), accounted for the TRU Waste Pad storage container arrays by only assuming a fraction of the containers were at risk. Since the location of B-25s in the LRWHF is much more random, all containers are assumed to be at risk.

The Solid Waste Authorization Basis, WSRC-SA-22 and supporting calculations (Ref. 2 and 3) assume that the B-25 is positively sealed. This assumption is critical for enabling B-25s at the TRU waste pads to contain TRU waste during the tornado event, as it is for B-25s containing potential sludge contaminated waste in Tank Farms.

- To assume positive closure for the Waste Container Safety Implementation the following requirements must be imposed:

- All waste containers not requiring access which contain potential sludge waste and actual sludge contaminated waste as defined in the HLW LLW Program shall be closed and sealed.

- At the onset of a High Wind Waming or Tomado Watch, all waste containers containing potential sludge waste or actual sludge contaminated shall be closed and sealed. To ensure containers can be closed in a timely fashion. a maximum of 10 containers with potential sludge waste or actual sludge waste should remain unclipped within a facility's boundaries.

- An Administrative Control program identifying waste containers requiring closure during Emergency Conditions (High Wind/Tomado Watch) will be maintained.

- B-25s shall be visually inspected periodically and immediately prior to use for potential sludge or actual sludge. contaminated waste. The inspection shall verify the following: 1) that the waste boxes contain no visually observable holes. 2) the boxes do not contain excessive rust: and 3) the boxes do not show evidence of excessive gasket wearidamage. Once verified. the boxes should be immediately used for potential sludge or TRU contaminated waste. 


\subsection{ISOTOPES}

Since various isotopic distributions for the waste contamination are possible, the TRU waste actinide (with a half life greater than 20 years) with the highest Effective Dose Equivalent (EDE) inhalation value is used in converting total curies to dose. This is conservative because Am-24l has the higher $\mathrm{rem} / \mathrm{Ci}(5.2 \mathrm{E}+8)$ value, while typically the vast majority of the TRU waste that would be generated from CST facilities is from plutonium isotopes which have a slightly lower rem/Ci value. Table I lists potential contributors to dose, (conservatively, irrespective of relative availability in Tank Farms: excluding those not expected to be present).

Table 1. EDE Values for TRU Waste Contributors

\begin{tabular}{|c|c|c|}
\hline Isotope & $\begin{array}{c}\text { Half Life } \\
\text { (years) }\end{array}$ & $\begin{array}{c}\text { EDE } \\
\text { (rem/Ci) }\end{array}$ \\
\hline $\mathrm{Np}-237$ & $2.14 \mathrm{E}+06$ & $4.90 \mathrm{E}+08$ \\
\hline $\mathrm{Pu}-238$ & 86.4 & $4.60 \mathrm{E}+08$ \\
\hline $\mathrm{Pu}-239$ & 24,390 & $5.10 \mathrm{E}+08$ \\
\hline $\mathrm{Pu}-240$ & 6580 & $5.10 \mathrm{E}+08$ \\
\hline $\mathrm{Pu}-242$ & $3.79 \mathrm{E}+05$ & $4.80 \mathrm{E}+08$ \\
\hline $\mathrm{Pu}-244$ & $7.6 \mathrm{E}+07$ & $4.80 \mathrm{E}+08$ \\
\hline $\mathrm{Am}-241$ & 458 & $5.20 \mathrm{E}+08$ \\
\hline $\mathrm{Am}-242 \mathrm{~m}$ & 152 & $5.10 \mathrm{E}+08$ \\
\hline $\mathrm{Am}-243$ & $7.95 \mathrm{E}+03$ & $5.20 \mathrm{E}+08$ \\
\hline $\mathrm{Cm}-243$ & 32 & $3.50 \mathrm{E}+08$ \\
\hline $\mathrm{Cm}-247$ & $1.6 \mathrm{E}+07 ; 4 \mathrm{E}+07$ & $4.90 \mathrm{E}+08$ \\
\hline
\end{tabular}

Although uranium is excluded from TRU Waste by definition, it emits alpha radiation and hence, are an inhalation hazard. Since the majority of the uranium is $U-238$ and the EDE is $1.20 E+08 \mathrm{rem} / \mathrm{Ci}$, assuming $100 \%$ Am-24l (with an EDE of 5.20E+08) ensures conservatism.

It should be noted that throughout this report "Ci" refers to "curies of alpha" or "inhalation curies" and represent equivalent $\mathrm{Pu}-238 \mathrm{Ci}$. Although the $\mathrm{Am}-241$ dose/ $\mathrm{Ci}$ value was used in our calculations, the results still conservatively represent the equivalent Pu-238 dose.

\subsection{B-25 DESIGN}

The specifications for B-25s are found in "Procurement Specifications for Low Level Waste Boxes (U)". M-SPP-G-00248 (Attachment 9). A review of the previous specification, "Procurement Specification for Low Level Waste Burial Box", M-SPS-G-00012 (Rev. 6), also revealed similar requirements.

B-25s are constructed of 12 or 14 gauge carbon steel. The size is $48^{\prime \prime} \times 48^{\prime \prime} \times 72^{\prime \prime}$. The weight of an empty B-25s is currently not less than $460 \mathrm{lb}$. (In fact, the weight of the B-25s has shown to be gradually increasing and values as high as $622 \mathrm{lb}$. have been recorded (Ref. 4)). Without an approved deviation request, the maximum weight of a loaded B-25 is restricted to $5000 \mathrm{lb}$. The top lid of the B-25 contains a gasket and a positive fastening mechanism. Procurement specifications require that the B-25 has 
WSRC-TR-98-00050

Revision 0

February 10.1998

Page 4 of 55

provisions to ensure fast, positive closure of the lid to the box. The closure mechanism is required to achieve twenty percent minimum compression of the gasket between the lid and box after closure.

A standing water test is also performed on representative boxes to ensure leak tightness. A load carrying test of 20,000 lb. with minimal deformation ensures that the boxes are capable of supporting a uniform load and may be stacked (applicable sections of Attachment 9).

Strict adherence to the procurement specification is required by the supplier to assure quality, reliability and integrity of the boxes. The following codes and standards are required to be followed (Attachment 9):

- Titte 49 CFR 173.24, Standard Requirements for All Packaging, 1990 revision.

- Title 49 CFR 173.411, General Design Requirements for All Packaging, 1990 revision

- Title 29 CFR 1910, Occupational Safety and Health Standards, 1990 revision

- ASTM A-569, steel, carbon (0.15\%) hot-rolled, sheet and strip, commercial quality, “1987 Book of ASTM Standards".

- ASTM D-1056-73, Specification for Flexible Cellular Materials -Sponge or Expanded Rubber, "1975 Book of ASTM Standards".

- AWS D1.1-90, Structural Welding Code - Steel.

- ASTM D-16-84, Type 1, Paint Finish Criteria, "1987 Book of ASTM Standards".

- AISC, American Institute of Steel Construction Handbook

- ASTM A-36, Specification for Structural Grade Carbon Steel, "1987 Book of ASTM Standards". 
WSRC-TR-98-00050

Revision 0

February 10.1998

Page 5 of 55

\subsection{INPUT VALUES AND ASSUMPTIONS}

\subsection{Methodology}

The analysis is primarily based on the Sold Waste Safety Analysis Report and supporting calculations (Ref. 2 and 3) of TRU waste containers. These documents have undergone a rigorous review process and have been formally approved and therefore the methodology was not re-validated. As with the SW analysis, the focus is on actinides (inhalation hazards) and therefore is restricted to potential sludge and TRU contaminated waste.

Supernate contaminated boxes are not a concern and are not addressed in this report because the volume of the supernate that would be required to exceed the similar onsite process guidelines is about 1200 gallons. According to the High Level Waste Characterization of Low Level Waste Certification Manual (U), WSRC-TR-94-0581, each waste box on average contains significantly less than 1 gallon of waste. Therefore all material at risk associated with the 1,200 boxes would have to be released. This is judged to be incredible. Refer to Attachment 1.

\subsection{Stacking}

The SW SAR (Ref. 2) assumed that the second level of B-25 boxes around the perimeter of the pad are susceptible to tipping and free falling to the concrete pad. B-25s are not qualified to withstand a free fall therefore, it is conservatively assumed that they will sustain some damage. In the LRWHF however, B25 s are not stacked on top of each other. Conservatively, based on the SW SAR and Attachment 10. we assume $1 \%$ of the B-25s to be damaged from uplift and free fall.

\subsection{Missile Strikes}

For conservatism, missiles are assumed to strike every potential sludge, actual sludge and TRU box, and is independent of the $1 \%$ which suffer from uplift. This assumption is equivalent to assuming that each box is a separate facility. This is conservative as the TRU pad SAR assumes a single missile strike per pad. (Note: This was assumed because unlike $S W$, there is no set configuration requirement for the location of the boxes.) This assumption will more than compensate for any potential rolling effect from the tornadic angular momentum which causes the boxes to roll. This conservatism assumes that the net effect of an object hitting a box is the same as a box hitting an object, thereby encompassing rolling.

\subsection{Release Period}

It is assumed that $100 \%$ of the radiological material susceptible to aerodynamic entertainment would be released over a 24 hour period.

\subsection{Positively Sealed}

In the SW analyses, the boxes are positively sealed and weigh in excess of the $350 \mathrm{lb}$, compared to 460 lb. Currently, at a minimum, the boxes used in the LRWHF are greater than or equal to $460 \mathrm{lb}$. (Ref. 4). 
WSRC-TR-98-00050

Revision 0

February 10, 1998

Page 6 of 55

Adequate controls ensure that the positively closure mechanism adequately works and that positive closure remains possible.

\section{$5.6 \cdot$ Material At Risk}

The material at risk (MAR) was determined for each defined box. The boxes were characterized as sludge boxes (potential and actual) or TRU boxes. The number of curies in each sludge box was arbitrarily set at the TRU Threshold limit.

\subsubsection{Sludge Box Material At Risk}

Sludge boxes contain $0.23 \mathrm{Ci}$ of TRU radionuclides (The TRU Threshold limit) (Refer to Attachment 11). This value, based on the TRU Waste Threshold Value and maximum waste weight allowed. was arbitrarily chosen to represent the maximized contents of all sludge boxes. The value represents the maximum curies which could be in a box before being considered as TRU waste.

\subsubsection{TRU Box Material At Risk}

Conservatively, a TRU waste B-25 box from Tank Farms does not have greater than $100 \mathrm{Ci}$ of MAR of Transuranic Waste per container. This value is based on process knowledge, Reference 8 (the 299-H Inventory Control Program) and flushing requirements. Also about 9 gallons of the current worst case sludge waste would be required to achieve this activity. In reality, all known TRU Waste is placed into a known TRU Waste Container. \{This value exceeds the value used in the EPHA HAD for F and H Tank Farms. The value used here is bounding and is not representative of an actual potential value.\}

\subsection{Boxes at Risk}

Since there are few controls on where the boxes may be placed (the location for storage of the boxes is not designated as in the TRU Waste Pads), all boxes were assumed to be at risk. This conservatively deviates from Reference 2 where only a fraction of the boxes were designated as at risk.

\section{$5.8 \quad$ Overall Dose}

The dose must be calculated by determining the impact of all containers during a tornado scenario. It is likely that if a Sludge box or TRU box was struck by the tomado, there would be some release associated supernate boxes. The supernate contaminated boxes, however, are not a concern and are not addressed in this report because of the volume of the supernate that would be required to exceed the onsite guideline is about 1200 gallons. According to the High Level Waste Characterization of Low Level Waste Certification Manual (U), WSRC-TR-94-0581, each waste box on average contains significantly less than 1 gallon of waste. Therefore all material at risk associated with the 1,200 boxes would have to be released. This is judged to be incredible. Refer to Attachment 1. 
WSRC-TR-98-00050

. Revision 0

February 10.1998

Page 7 of 55

\subsection{Controls}

The B-25s are adequately controlled and inspected immediately prior to use to ensure leak tightness (positive seal) and potential leak tightness (free from rust or unpainted metal surfaces) capabilities. The inspection should consists of visually verifying that the waste boxes contain no visually observable holes, do not contain excessive rust, and show no evidence of excessive gasket wear/damage. Once verified the boxes can be immediately used for potential sludge or TRU contaminated waste.

Since the impact of supernate contaminated waste boxes has been shown to negligible, boxes which do not pass the visual inspection may be considered for use with supernate contaminated waste.

\subsection{SOURCE TERM}

The source term is the amount of radioactive material, in mass or activity (curies), released to the air. The initial source term is the amount of radioactive material driven airborne at the accident source. The initial restorable source term, a subset of the initial source term, is the amount of radioactive material driven airborne at the accident source that is effectively inhalable. Lesser source terms are determined by applying filtration or deposition factors to the initial source term.

\subsection{General Five Factor Formula}

The source term is calculated using a variation of the five factor formula, as given below:

$S T=M A R \times D R \times A R F \times L P F \times R F$

MAR = Material at Risk - The amount of radionuclides (curies) available to be acted on by a given stress. For facilities, processes, and activities, the MAR is a value representing some maximum quantity of radionuclide present in a discreet physical location that are separated from other radionuclide bearing areas by adequate distance or physical barriers so that the areas do not interact during the postulated accident conditions.

DR = Damage ratio - The fraction of MAR impacted by the accident-generated conditions. (A degree of interdependence exists between the definitions of MAR and DR.) The DR is estimated based upon engineering analysis of the response of structural materials and materials-of-construction for containment to the type and level of stress/force generated by the event. Standard engineering approximations are typically used. These approximations often include a degree of conservatism due to simplification of phenomena to obtain a useable model. but the purpose of the approximation is to obtain. to the degree possible, a realistic understanding of potential effects.

$A R F=$ Airborne Release Fraction (or Airborne Release Rate) - The Airborne Release fraction is the coefficient used to estimate the amount of a radioactive or hazardous material than can be suspended in air as an aerosol and is available for transport under a specific set of accident conditions. Airborne Release Rate is the coefficient used to estimate the amount of a radioactive or hazardous material that can be suspended in air by continuously acting mechanisms such as aerodynamic entertainment/resuspension. 
WSRC-TR-98-00050

Revision 0

February 10.1998

Page 8 of 55

LPF = Leak Path Factor - The fraction of airborne materials transported from containment by the existing flow via the pathway configuration under evaluation. There can be many LPFs for some accident conditions (e.g., the fraction transported from the package, such as a shipping container, to the cell or enclosure; the fraction leaked from the enclosure, cell, or glovebox to the operating area around the enclosure or room: the fraction leaked from the room to the building-atmosphere interface). When multiple leakpaths are involved, their cumulative effect is normally expressed as one value that is the product of all leakpaths. The LPF is a calculated or standard value based upon the established relationships between size of the particulate material, airborne transport mechanisms, and losses by deposition mechanisms, or specified filtration efficiencies.

RF = Respirable Factor - The fraction of airborne, radionuclides as particles that can be transported through air and inhaled into the human respiratory system. These particles are commonly assumed to be $10 \mu \mathrm{m} \mathrm{AED}$ and less. (Aerodynamic Equivalent Diameter - the diameter of a sphere on density $1 \mathrm{~g} / \mathrm{cm}^{3}$ that exhibits the same terminal yelocity as the particle in question.)

\subsection{Modified Source Term Formula}

Reference 3 modified the above formula to be:

$\mathrm{ST}=$.number $\times \mathrm{CD} \times \mathrm{CI} \times \mathrm{MRF} \times \mathrm{ARF} \times \mathrm{RF} \times \mathrm{LPF}$

Where:

number - the total number of potential sludge and/or TRU B-25s per facility = this number is calculated to determine the number of boxes allowed.

CD - represents the ratio of potential sludge and /or TRU B-25s damaged $=$ As discussed above this value is $\mathrm{l} \%$ for uplift and conservatively assumed to be 1.0 for missile penetration. (Note: The CD for uplift and missile damage are completely independent.)

$\mathrm{Cl}$ - represents the container inventory = This value is calculated from the TRU threshold for sludge boxes ( $0.23 \mathrm{Ci}$ alpha) and conservatively assumed to be $100 \mathrm{Ci}$ alpha for potentially TRU contaminated boxes. Also refer to Section 5.6.1 and 5.6.2.

MRF - represents the material released from a damaged container $=$ The value listed in Reference 5 is $1.0 \mathrm{E}-01$. This value is also used for our determination.

The relationship of terms in the five factor formula to the modified formula is as follows:

$\mathrm{MAR}=$ number $\times \mathrm{CI}$

$\mathrm{DR}=\mathrm{CD}$

$(\mathrm{LPF})_{\text {total }}=\mathrm{MRF} \times \mathrm{LPF}$ 


\subsubsection{Number}

For the LRWHF analysis. all the applicable potential sludge and potential TRU boxes in the facility are assumed to be at risk. This is conservatively different than the SW SAR analysis which only assumed a fraction of the total were at risk. As noted in Section 5.I and 5.8, supernate boxes are not considered.

\subsubsection{Container Damage (CD)}

References 2 and 3 considered damage from container uplift, missile penetration, atmospheric pressure change (APC) and tornado wind/container roll. Each are discussed in dẹtail in the following paragraphs. The references concluded that B-25 boxes would fail under certain stresses and storage configurations such as stacked B-25s, while large boxes and concrete culverts would not fail. Applying the values from References 2 and 3 is conservative.

\section{2 .2 .1 Uplift}

The tornado wind uplift of the containers is based on wind speed, container orientation, and lift and drag coefficients. Tornado wind forces were estimated using computer programs and codes to determine if the containers receive a net positive upward force (Ref. 3 ). Containers which receive net positive upward force, or are lifted, are assumed to fail by perforation or some breaching mechanism. For the uplift/fallback model $1 \%$ of the at risk B-25 boxes were calculated to fail (Ref. 2 and 3).

The approximation that $1 \%$ of the boxes fail is based on the weight of a B-25 being $350 \mathrm{lb}$. however B-25s currently weigh at least $460 \mathrm{lb}$. (empty). Since the vertical force for a B-25 caused by a PC-3 tornado is $554 \mathrm{lb}$. (Ref. 3, Page 111-also see Attachment 9 and 10), and the weight of the waste must also be taken into account, the $1 \%$ approximation is very conservative. Also refer to Section 8.0.

\subsubsection{Missile Penetration}

Five missiles were analyzed in Reference 3, including a two by four timber, a 3 in diameter steel pipe, an automobile, a TRU pad cover frame, and a 55 gallon drum. According to Reference 3. the timber weighs 15 pounds and travels at a speed of $150 \mathrm{mph}$ horizontally or $100 \mathrm{mph}$ vertically. The 3 in diameter steel pipe travels at a speed of $75 \mathrm{mph}$ horizontally or $50 \mathrm{mph}$ vertically. Conservatively, in our calculation, each B-25 is assumed to be hit by a missile. This assumption will more than compensate for any potential rolling effect. This conservatism assumes that the net effect of an object hitting a box is the same as a box hitting an object, thereby encompassing rolling.

\subsubsection{Atmospheric Pressure Change (APC).}

This calculation assumes that the B-25s which potentially contain TRU waste are sealed and do not fail during APC. This is consistent with Reference 2 and 3. 


\subsubsection{Rolling}

Rolling is not explicitly addressed in this analysis. The SW SAR did not credit rolling as a possible release mechanism for B-25s. However, in this analysis it was conservatively estimated that any potential effect from rolling caused by the tornadic angular momentum rolling these boxes is more than compensated for by assuming that the total box population is hit by individual missiles. See missile penetration.above.

\subsubsection{Container Inventory (C)}

The amount of TRU waste per container can vary due to processes and concentration. However, known TRU waste must be placed into an approved TRU waste container. Therefore, in reality our concern is waste which has a potential to be TRU once segregated from the non-TRU portion during the Waste Characterization. For a maximum weight ( $5000 \mathrm{lb}$.) B-25 the TRU Threshold is about $0.23 \mathrm{Ci}$. (Refer to Attachment (1). For conservatism for a B-25 containing TRU waste we assumed a MAR of $100 \mathrm{Ci}$. \{As noted in Section 5.6.2, this value is bounding and does not represent a foreseeable realistic number of a releasable material, but represents a conservatively bounding number.\}

\subsubsection{Material Release Fraction (MRE)}

Since the SW SAR looked at B-25s during a PC-3 tornado, the same value is used for the LRWHF. Consistent with Reference 3, a MRF of 0.1 is applied. (A similar box with the same forces acting on it will result in a similar fraction of the overall material released.)

\section{2 .5 Airborne Release Eraction(ARF)}

A value of $2 \mathrm{E}-04$ is used in Reference 5 and will be applied to this scenario.

(Note: The Respirable Fraction (RF) value is not explicitly discussed in Reference 5. However, a value of 1.0 can be implied, and therefore will also be used for this scenario.\}

\subsection{OTHER RELEASE FRACTIONS}

It should be noted that the TRU Waste Pad Section of the SW SAR did not analyze removed HEPA filters. Any effect from a removed HEPA filter release in a B-25 could consider the additional ARF factor which would further minimize the amount of material released. DOE-HDBK-3010-94 states that "Dislodging all of the contaminant is difficult since much of it penetrates into the medium." Conservatively, for the purpose of this analysis, no attempt has been made to further evaluate HEPA filters or quantify this statement. (Note: Not crediting the confinement capability/additional release fraction associated with a HEPA filter in a HEPA filter scenario may result in undue conservatism.)

\subsection{DISPERSION}

The dispersion factors $(\mathrm{X} / \mathrm{Q})$ and breathing rates are based on worst case information provided in Reference 6. The Reference 6 X/Q of $6.7 \mathrm{E}-7 \mathrm{~min} / \mathrm{m}^{3}$ uses $95 \%$ adverse dispersion conditions (95\% worst case meteorology) for the LRWHF. Note, these values were chosen over using those in the Hazard and Accident Analyses for the Liquid Radioactive Waste Handling Facilities,(U), Ref. 7. Reference 7 states 
WSRC-TR-98-00050

Revision 0

February 10.1998

Page 11 of 55

a value of $6 \mathrm{E}-7 \mathrm{sec} / \mathrm{m}^{3}$ for an $\mathrm{F} 2$ tornado at any receptor. Changing the units in Reference 7 results in a value of $1 \mathrm{E}-8 \mathrm{~min} / \mathrm{m}^{3}$ compared to an offsite value of $6.7 \mathrm{E}-7 \mathrm{~min} / \mathrm{m}^{3}$ used in this analysis.

Supporting the use of the more conservative dispersion factor is UCRL-15910 which uses an approximate wind speed of $190 \mathrm{mph}$. This means that the analyzed tornado was approximately an F3 tornado based on listed windspeeds. Therefore, to account for any potential inconsistencies, the more conservative value was chosen. (Also note: An onsite X/Q was applied based on Reference 6 . This approach is also extremely conservative since for natural phenomena events, onsite consequences are not frequently determined.)

\subsection{WEIGHT}

Waste weights of $90 \mathrm{lb}$. are required to ensure that no uplift will occur. Although no controls are required to ensure this limit, filling B-25 containers with less than $90 \mathrm{lb}$. of waste is not practical and not expected to occur. Conservatively $1 \%$ of the B-25s are assumed to suffer uplift. This is conservative because based on the 1995, 1996, and 1997 certification reports, all B-25s with waste contained significantly greater than $90 \mathrm{lb}$. of waste. 
WSRC-TR-98-00050

Revision 0

February 10.1998

Page 12 of 55

\subsection{RESULTS}

The TRU Waste Pads and the LRWHF are both Hazard Category Two Facilities. The SW analysis of tornado events hitting TRU B-25s has been applied to potential sludge boxes and potential TRU boxes in the LRWHF. The results are calculated in Attachment 4-8 and shown in Table 1.

Table I Curies allowed before Offsite Limits/Onsite Guidelines Exceeded

\begin{tabular}{|c|c|c|}
\hline Closure Method & $\begin{array}{l}\text { Ci Threshold for Onsite } \\
\text { Guideline } \\
\text { (Eq. } \alpha \text { Ci) }\end{array}$ & $\begin{array}{l}\text { Ci Threshold for Offsite Limit } \\
\text { (Eq. } \alpha \mathrm{Ci})\end{array}$ \\
\hline Positive Closure (Sealed) & $\begin{array}{l}4.4 E+05 \\
\left.\text { (Sludge }=1.96 E+06 B-25 s^{*}\right) \\
\left(T R U=4.44 E+103 B-25 s^{* *}\right)\end{array}$ & $\begin{array}{l}8.8 \mathrm{E}+05 \\
\left(\text { Sludge }=3.9 E+06 \quad B-25 s^{*}\right) \\
\left(T R U=8.88 E+03 B-25 s^{* *}\right)\end{array}$ \\
\hline $\begin{array}{l}\text { Non-positive Closure } \\
\text { (unsealed/chained) }\end{array}$ & $\begin{array}{l}8.8 \\
\left(S / u d g e=39 B-25 s^{*}\right) \\
\left(T R U=0.01 \quad B-25 s^{* 4}\right)\end{array}$ & $\begin{array}{l}18 \\
\text { Sludge }=-\left(-B-25 s^{*}\right) \\
\left(T R U=0.18 B .25 s^{* *}\right)\end{array}$ \\
\hline
\end{tabular}

Note * Represents the number of potential sludge B-25s loaded to $0.23 \mathrm{Ci}$ of alpha. See Section 5.6.1.

Note ** Represents the number of potential TRU B-25s loaded to $100 \mathrm{Ci}$ of alpha. See Section 5.6.2.

Note (1) Extremely conservative because for natural phenomena events only offsite consequences are normally determined.

Note (2) Because analysis analyzed a $190 \mathrm{mph}$ wind. conservative X/Q applied (Ref. 6 vs. Ref. 7) and results conservative.

The results show that significantly less than one non-positively sealed B-25 containing $100 \mathrm{Ci}$ of TRU waste could cause the Offsite/Onsite Limits and Guidelines to be exceeded, while if positively closed in excess of 4000 boxes would be required. For boxes defined as sludge boxes, greater than 30 unsealed boxes could cause the Offsite/Onsite Limits and Guidelines to be exceeded, while if positively closed, in excess of $1.5 \mathrm{E}+06$ would be required.

\subsection{CONCLUSION}

Known TRU waste should always be placed directly into approved TRU Waste Containers. Any TRU waste scenario which looks at the impact of a tornado on a 55 gallon drum requires an additional leak factor associated with rolling (and therefore the resultant values should not be directly applied to drums).

Based on Reference 2 and 3 and the results calculated, it is recommended that B-25s which may contain potential sludge waste or potential TRU waste and are full (or no other waste will be place into them) must be closed and positively sealed (clipped) as designed and allowed by the IS manual:

As part of this control it is necessary that an B-25s be visually inspected periodically and immediately prior to use for potential sludge or TRU contaminated waste. The inspection shall verify the following:

- That the waste boxes contain no visually observable holes

- The boxes do not contain excessive rust

- The boxes do not show evidence of excessive gasket wear/damage .' 
WSRC-TR-98-00050

Revision 0

February 10, 1998

Page 13 of 55

Once verified the boxes can be immediately used for potential sludge or TRU contaminated waste. Any boxes that fail the inspection should be potentially considered for supernate contaminated waste.

As a good practice, full containers should be characterized and transported for disposal in a timely fashion.

Procedures should ensure the following:

- All full B-25s are clipped and that the only open B-25s are those to which waste is currently being added.

As a good practice and to ensure adequate control and the ability to respond to all conditions within a timely fashion, it is recommended that a maximum of 10 containers with potential sludge waste or TRU waste remain unclipped within a facility's boundaries.

Controls should be required that upon High Wind/ Tornado Watch:

- B-25s which contain potential sludge waste and potential TRU waste that are not closed or positively sealed should be sealed as designed and allowed by the IS Manual.

As part of this control, an Administrative Control Program will be required identifying containers requiring closure during Emergency Conditions.

\subsection{References}

1. Natural Phenomena Hazards Design and Evaluation Criteria for Department of Energy Facilities, DOE-STD-1020-94, U.S. Department of Energy, Washington, DC April 1994.

2. Safety Analysis Report, Solid Waste Management Facility Chapter 3, Hazard and Accident Analysis, WSRC-SA-22, Rev. 0, December 1996.

3. Tornado Evaluation of the SWMF TRU Waste Storage Pads (U), S-CLC-E-00027, Rev. 0, $3 / 31 / 95$.

4. Waste Inventory Logsheet, FT14003928, Page I (Tare Weight)

5. DOE Handbook, Airborne Release Fractions/Rates and Respirable Fractions for Nonreactor Nuclear Facilities, October 1994.

6. Emergency Preparedness Hazard Assessment for the F and H Tank Farms, Rev. 0, 12/16/96.

7. Hazard and Accident Analyses for the Liquid Radioactive Waste Handling Facilities (U), WSRC-TR-96-0102, Rev. 2, 12/13/96.

8. Inventory Control Program for the 299-H Facility, WSRC-TR-97-00342, Rev. 0, 12/18/97. 


\begin{tabular}{|c|c|c|c|c|c|c|c|c|}
\hline \multicolumn{9}{|c|}{ The Onsite Guideline can be exceeded } \\
\hline \\
\hline & & & & & & & & \\
\hline \multicolumn{9}{|l|}{ Therefore } \\
\hline & CiLimit & $\mathrm{g} / \mathrm{Ci}$ of $\mathrm{Pu}-238$ & $g$ of Pu-238 & con & sol & con & & \\
\hline & $A$ & $\bar{B}$ & $C=A \sqrt{B}$ & $1000 \mathrm{mg} / \mathrm{g}$ & $1 \mathrm{~L} / 0.1 \mathrm{mg}$ & gal/3.785L & & \\
\hline & 8.8 & 17.15 & 0.51311953 & 513.1195 & 5131.195 & 1355.666 & & \\
\hline & & & & & & & & \\
\hline & & & & & & & & \\
\hline & & & & & & & & \\
\hline \multicolumn{9}{|c|}{ Conservatively, we can say roughly 1200 gallons are required. } \\
\hline & & & & & & & & \\
\hline \multirow{2}{*}{\multicolumn{9}{|c|}{ Since on average less than 1 gallon is associated with a B-25, we can conclude 1200 boxes would be required }} \\
\hline & & & & & & & & \\
\hline & & & & & & & & \\
\hline Note: $8.8 \mathrm{C}$ & Ci was calcu & ulated in Attachm & nent $8 A$ and 8 & & & & & \\
\hline
\end{tabular}


WSRC-TR-98-00050

Revision 0

February 10. 1998

Page 15 ot 55

Attachment 2

WSRC-SA.22

Rov. 0

Haard Classificarion Table

\begin{tabular}{|c|c|c|c|}
\hline Facility & $\begin{array}{c}\text { Radiologien } \\
\text { Hezard } \\
\text { Claccifiearion }\end{array}$ & $\begin{array}{l}\text { Cbeonied } \\
\text { Heand } \\
\text { Charifearios }\end{array}$ & $\begin{array}{l}\text { Facility } \\
\text { Henes } \\
\text { Clesifiernoa }\end{array}$ \\
\hline Old Burial Grounds & 2 & 3 & 2 \\
\hline TRU Ware Storage Pads & 2 & 2 & 2 \\
\hline $\begin{array}{l}\text { Greuter Confinemeat Disposel } \\
\text { Fecility }\end{array}$ & 3 & NA & 3 \\
\hline Used Equipaem Storige Are & 3 & NA & 3 \\
\hline $\begin{array}{l}\text { Navil Reacer Componem Stonge } \\
\text { Area }\end{array}$ & 3 & NA & 3 \\
\hline Enginaned Low-Leved Treocbes & 2 & 2 & 2 \\
\hline Solven Stanges Teris & 3 & Geonilum & 3 \\
\hline Moxed Wew Stango Building & 3 & 3 & 3 \\
\hline Mixed Wese Mrangeween Freilin' & 2. & 2 & 2 \\
\hline N Are & 3 & 3 & 3 \\
\hline 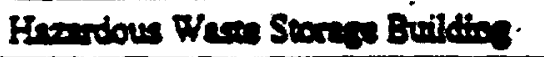 & $\mathbf{N A}$ & 3 & 3 \\
\hline E-Area Low-Activity Wase Veules" & 3 & $\mathbf{N A}$ & 3 \\
\hline 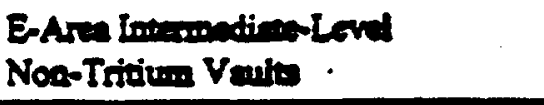 & 3 & $\mathbf{N A}$ & 3 \\
\hline 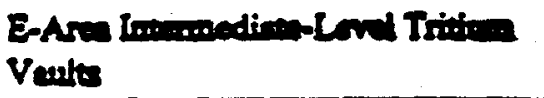 & 3 & NA & 3 \\
\hline 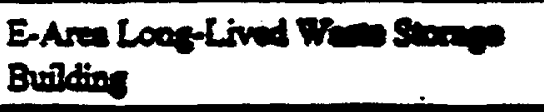 & 3 & NA & 3 \\
\hline 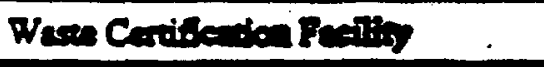 & 3 & $\cdot 3$ & 3 \\
\hline Comparex Brilesies & 3 & NA & 3 \\
\hline
\end{tabular}


WSRC-TR-98-1000ミ0

Revision 0

February 10. 1998

Page 16 of 55

Attachment 3

DOE.STD-1020.94

Recommended Basic Wind Speeds for DOE Sites, in miles per hour

\begin{tabular}{|c|c|c|c|c|c|c|}
\hline \multirow{3}{*}{ Pentormence Cetegory } & \multicolumn{6}{|c|}{ Fistest-mile Wind Soesed it tom Meight } \\
\hline & \multirow{2}{*}{$\frac{1}{\text { Ning }}$} & \multirow{2}{*}{$\frac{2}{\text { Wing }}$} & \multicolumn{2}{|c|}{3} & \multicolumn{2}{|c|}{4} \\
\hline & & & Ning & Tomago & Wing & $=-m a 00^{4}$ \\
\hline DCE PROJECI SITES & $2 \times 10 \cdot 2$ & $2 \times 10.2$ & $1 \times 10.3$ & $2 \times 10.5$ & $\times 104$ & $2 \times 104$ \\
\hline Kacsas Cing Piant NO & 72 & 72. & $\ldots$ & 14 & $\ldots$ & .98 \\
\hline ies Alamos National Laoorntory NM & $\pi$ & 7 & 93 & 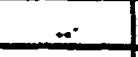 & 407. &. \\
\hline vourd Laporaten OH & 73 & 73 & - & 136 & - & 198 \\
\hline Pantex Piant TX & in & $\therefore$ & $=$ & $: 32$ & 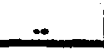 & 482 \\
\hline Focky flats Plent co & 109 & $\log$ & 130 & (3) & $: 61$ & (3) \\
\hline 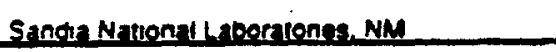 & 9 & 78 & 23 & 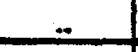 & 108 & - \\
\hline Sandra Notionet Laborntone, CA & 72 & $i 2$ & 96 & $\therefore$ & 113 & $=$ \\
\hline Pinellas Plane $\mathrm{FL}$ & 93 & 93 & 130 & - & 150. & $=$ \\
\hline Aroonat National heortron-Enth ith & 70(11) & rot11 &. & 142 & - & 198 \\
\hline 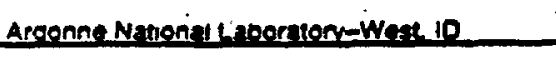 & $70 x^{11}$ & $70(11)$ & 83 & $\ldots$ & 35 & - \\
\hline Brooknaven Nation 1 Lapornos. NY & 70 (1) & TQ11) & - & 9912 & - & 145 \\
\hline Panceton Piasme Physes Laborntory Nes & $70(1)$ & To(i) & - & 103 & $\therefore$ & 190 \\
\hline : cane Namongy Enounenne Laboratory & 70111 & 7041 & es & - & 98 & - \\
\hline Eesed Matenals Production Crates OH & 7011 & $70(1)$ & - & 139 & - & 19 \\
\hline 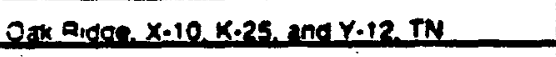 & 7011 & to(11) & $=$ & 113 & 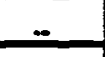 & 173 \\
\hline 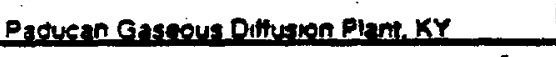 & $70 ! 11$ & sedn & $\sim$ & 14 & - & on. \\
\hline Ponsmoun Gasiour Domexen Pien. OH & 70411 & ton & - & 119 & - & 168 \\
\hline Venagh Tert Sire NV & 72. & 72 & 87 & $=$ & 100 & $=$ \\
\hline Eantorg Proinet Sile wa & 70 (1) & Fo11) & exp' & - & 9xil & - \\
\hline 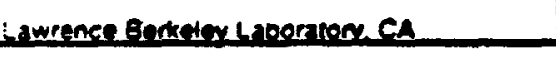 & 72 & 72 & 98 & - & 111 & $\therefore$ \\
\hline 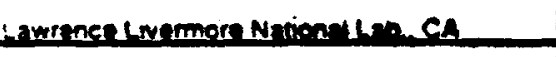 & $m$ & $m$ & 92 & 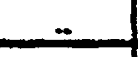 & 113 & - \\
\hline LWNLES Sil 300.CA & $\infty$ & 80 & 104 & - & $\therefore 25$ & - \\
\hline 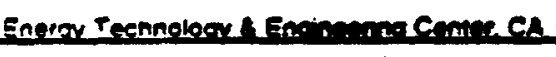 & 70 (11) & ton" & - & gs:a & $\ldots$ & 111 \\
\hline 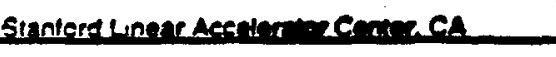 & 72 & 7 & 95 & 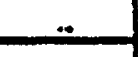 & 112 & - \\
\hline Saynangn Piver Sin se & 7. & is. & $\therefore$ & 132 & - & 192 \\
\hline
\end{tabular}

NOTES:

(1) Minkmum stragin wind speced.

(2) Minimum tomade soove

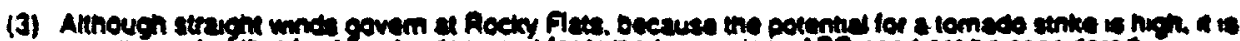

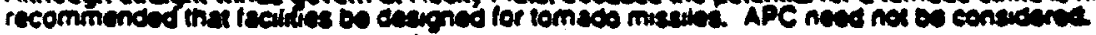

(4) Tomado spend netudes rotwond end transtational effects

(5) Humcane eftects aduminents as oer Table 3 -1 


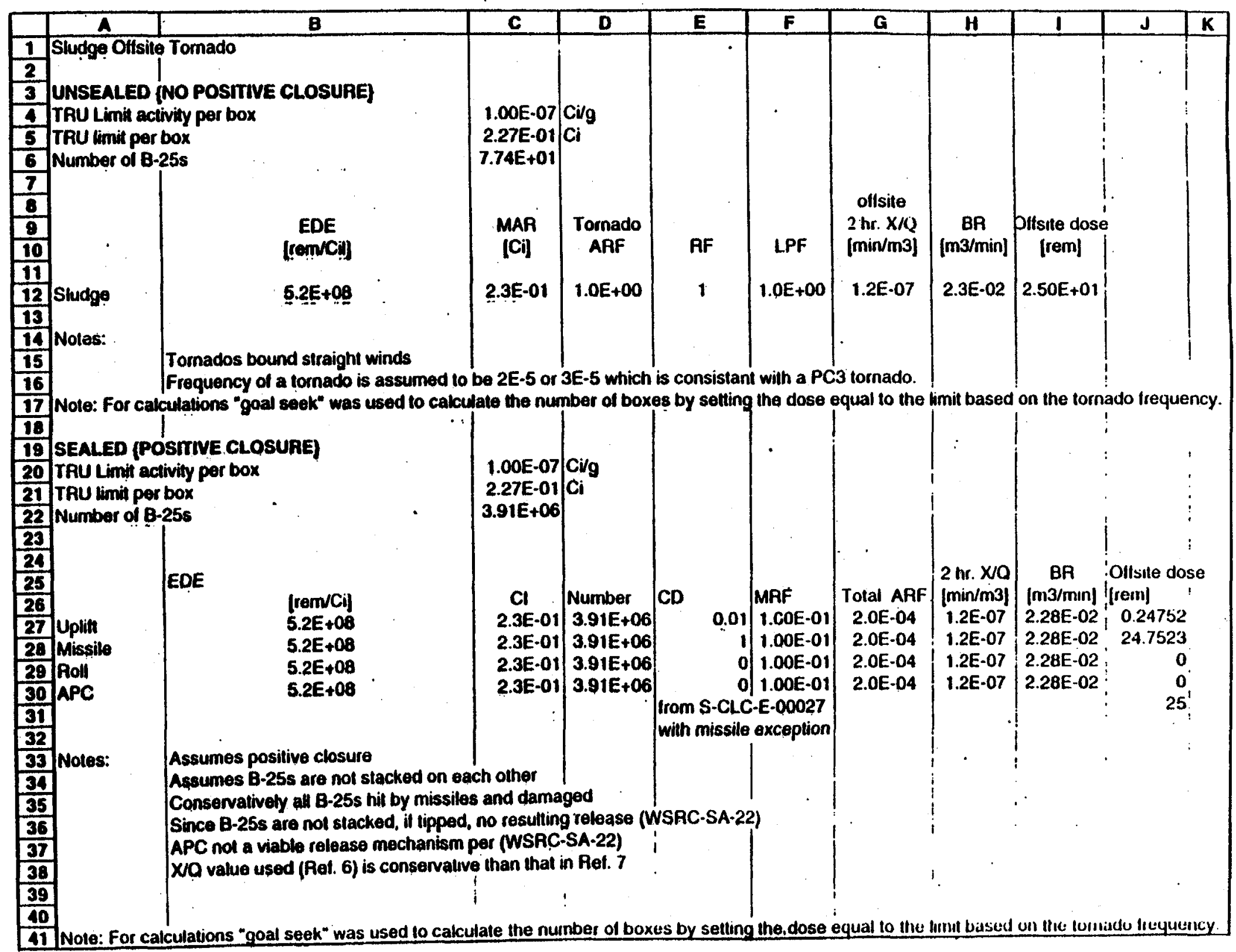




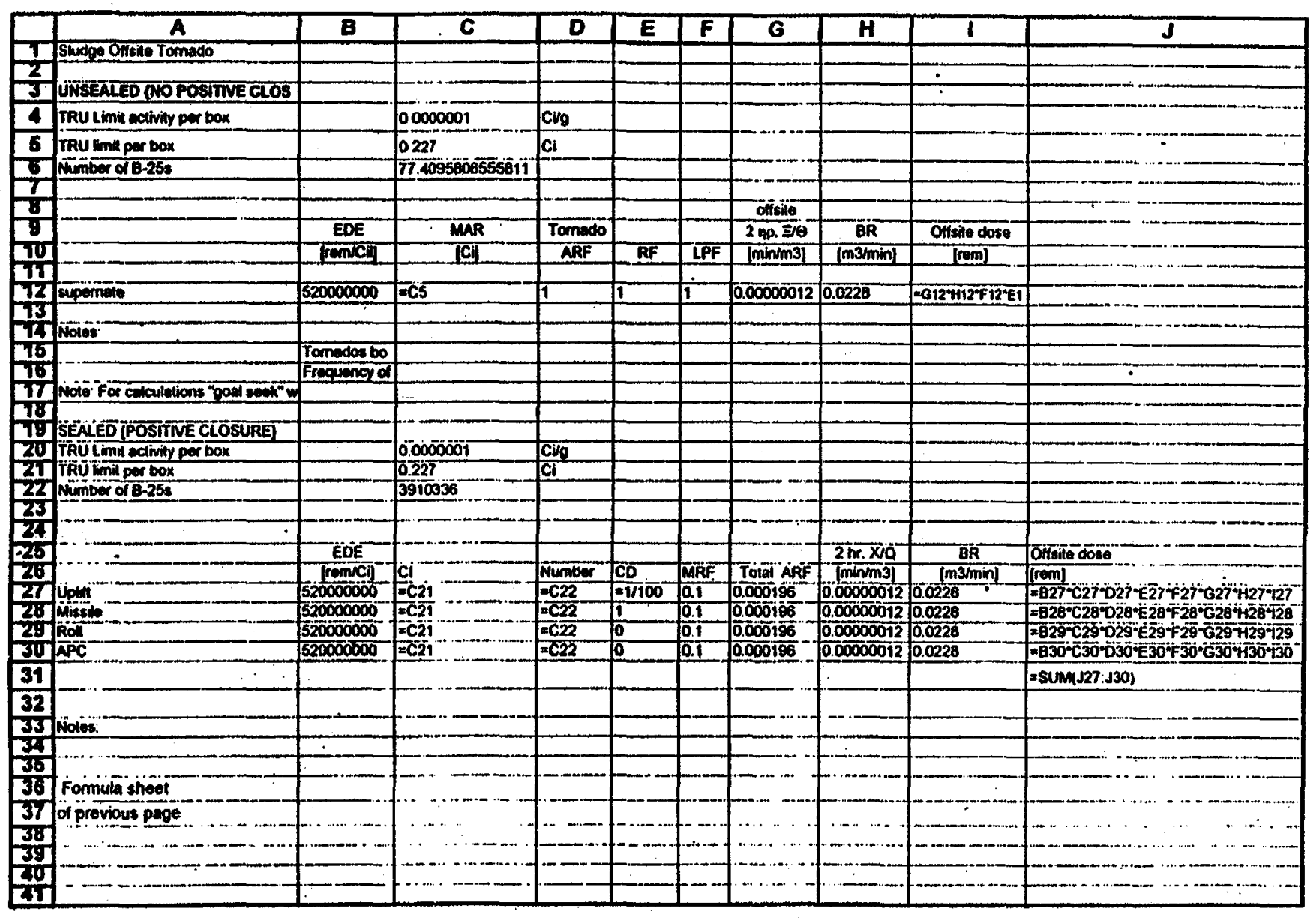




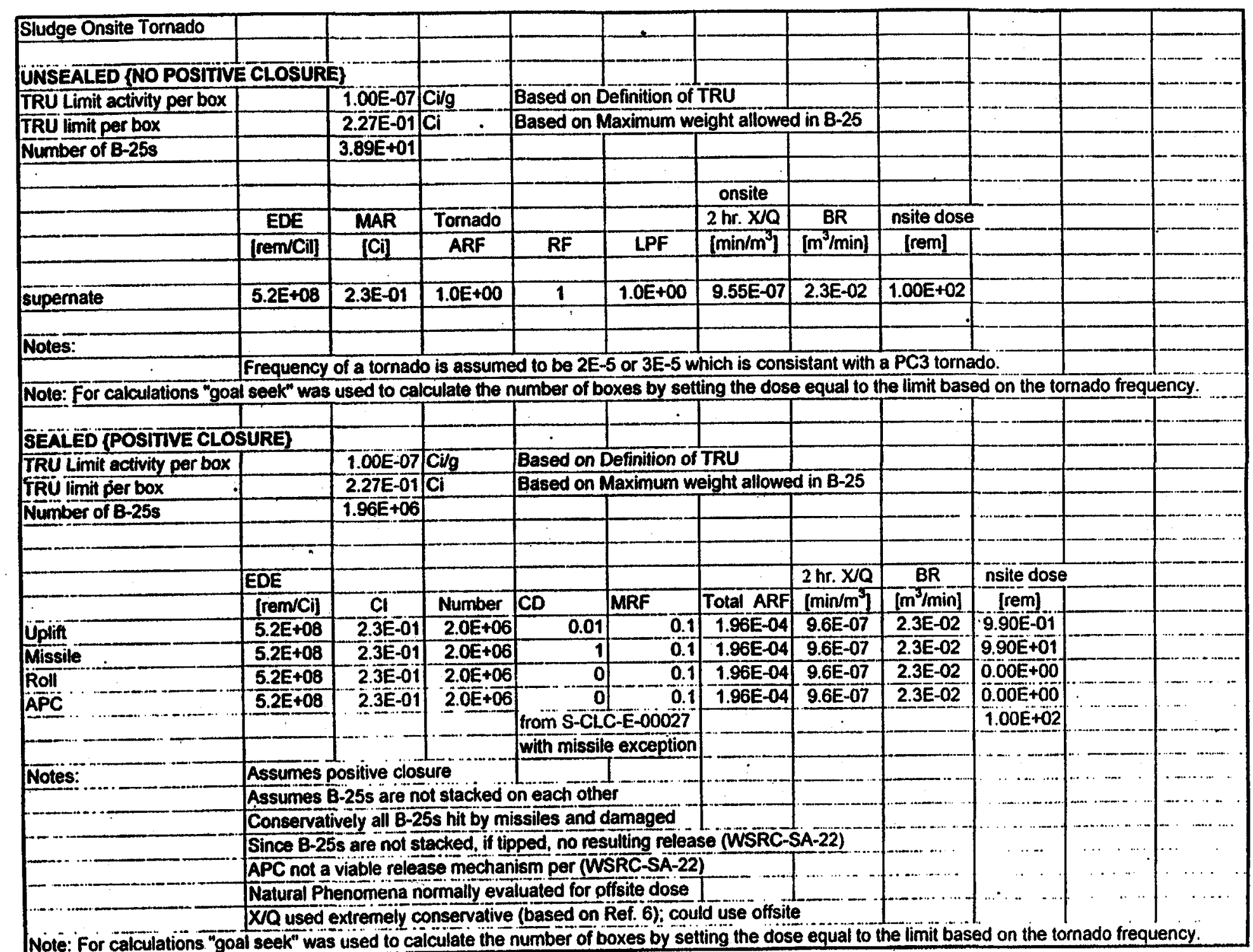




\begin{tabular}{|c|c|c|c|c|c|c|c|c|c|c|}
\hline & $\mathbf{A}$ & B & C & $\mathbf{D}$ & $\mathbf{E}$ & $\mathbf{F}$ & $\mathbf{G}$ & H & I & $\mathrm{J}$ \\
\hline 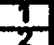 & Shopg Onsie Tomedo & & & & & & & & & \\
\hline 3 & UNSERLEO MOO POSTIVEE CLO & & & & & & & & & $-1+\cdots+\cdots$ \\
\hline 4 & TRU Limit edtivity per box & & 0.0000001 & $\operatorname{cing}$ & & & & & & \\
\hline 6 & TRU Imit per bax & & $=C 44454-5000$ & ci & & & & & & \\
\hline 6 & thimber d B-25e & & 36.90743332090979 & & & & & & & $-1-1-\cdots$ \\
\hline$\frac{7}{8}$ & & & & - & & & onsite & & & |..................... \\
\hline $\mathbf{y}$ & & EDE & TAR & Tornado & & & $2 \mathrm{hr} \times 1 \mathrm{O}$ & $B R$ & Onsilte doso & - n \\
\hline IUT & & fremicil & [C] & ARF & $\ldots \ldots$ & LPF & {$[\min / m 3$} & $-\mid \mathrm{m} 3 / \mathrm{min}$ & Irom] & - \\
\hline $\mathbf{2}$ & supensite & 520000000 & $\times \mathrm{CE}$ & 1 & 1 & 1 & 0.000000955 & 0.0228 & 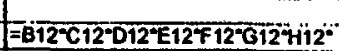 & $\ldots$ \\
\hline 13 & & & & & & & & & & {$[\ldots \ldots$} \\
\hline$\frac{76}{16}$ & Notos: & & & & & & & & & 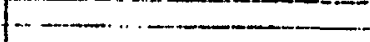 \\
\hline 76 & Hote: For calatations poal sook & & & & $-\infty$ & & & & & - \\
\hline 17 & & & & & & & & & & \\
\hline 18 & SEALED (POSITINE CLOSURE) & & & & & & & & & \\
\hline 19 & TRU Lind edivly per bax & & 0.0000001 & civg & & & & & & 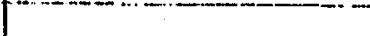 \\
\hline 201 & Tripun & & $-C 10^{\circ} 4543000$ & ci & Graxinum waight allow & & & & & 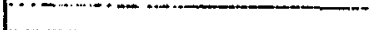 \\
\hline 27 & Number of B-253 & & 1955102.37663117 & & $+\infty$ & & & & & 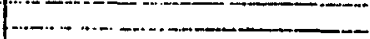 \\
\hline$\frac{22}{23}$ & & $\ldots$ & & & $\because$ & & & & & 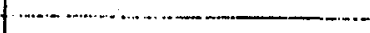 \\
\hline 24 & & EDE & & & & & & $2 \sqrt{n}$ cá & $-\cdots$ & Onisite dose............ \\
\hline 25 & & rromeis & CI & Number & Co & MRFF & Tolal ARF & minim3 & $(\mathrm{m} 3 \mathrm{~min})$ & [rem] $=$ \\
\hline 26$]$ & ijipin & 520000000 & $=C_{20}$ & $=\mathrm{C21}$ & {$[\overline{110} 100$} & $\overline{0.1}$ & $=(0.0010 .1)+0.00000$ & $0 \overline{0000 \overline{098}}$ & 00228 & 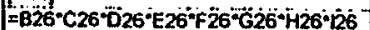 \\
\hline $2 \pi$ & Minsene & 520000000 & $=020$ & EC21 & $1 \ldots$ & $\overline{0.1}$ & $10.0010 .1)+1000000$ & $0.000000 \overline{96}$ & 0.0228 & $=B 27 \cdot \bar{C} 27 \cdot D 27 \cdot E 27 \cdot F 279$ \\
\hline 28$]$ & R에 & 520000000 & $=\bar{c} 20$ & $=\mathrm{C} 21$ & e. & 0.1 & $=(0.0010 .1)+(0.00000$ & 0.00000096 & 0.0228 & 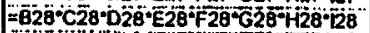 \\
\hline 29 & $\overline{A P C}$ & 520000000 & $=20$ & $=021$ & & 0.1 & $=0.0018 .1)+(0.00000$ & 000000096 & 02023 & 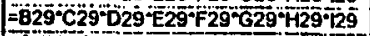 \\
\hline 30 & & & $\therefore$ & & From S-CLC-E-00027] & & & & (1) & SSUMM(J26 J29) - \\
\hline$\frac{3 y}{32}$ & Noiet: & & & & with missile excaption & & & & & - \\
\hline 35 & & & & - - & $-\cdots-$ & & & 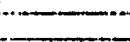 & & - \\
\hline 34 & Formula sheet & & & & . & & & & ( & - \\
\hline 36 & of previous pape & & & & & & & & & $\ldots$ \\
\hline$\frac{36}{37}$ & Whil For calculations poi Bock" & -......... & - & $+-\cdots$. & $\cdots \cdot \cdots$ & $-\infty$ & $-\cdots \cdots$ & & $\cdots$ & $\cdots \quad, \quad \cdots \cdots+\cdots$ \\
\hline
\end{tabular}




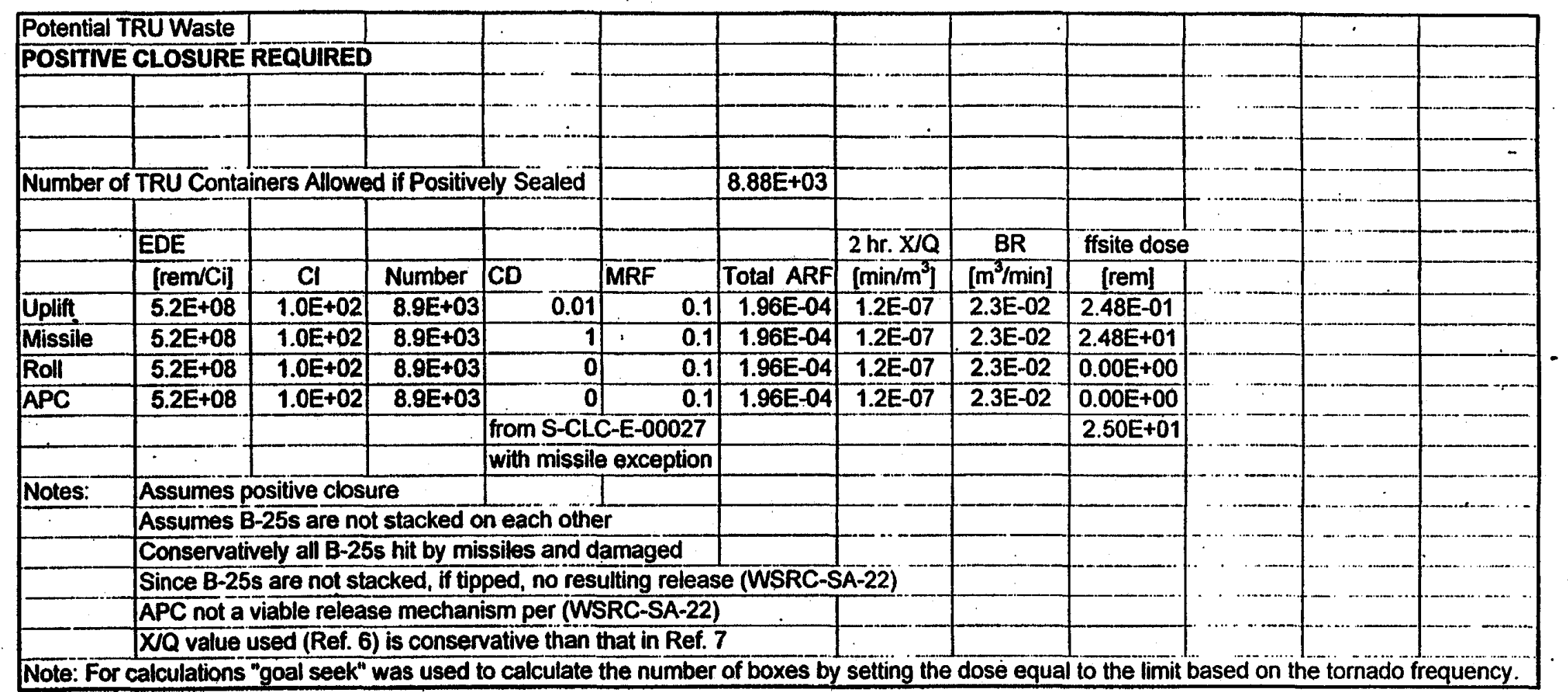


Attachment 6 - TRU Dose from a PC-3 Tornado, Oftsite (CALC)

\begin{tabular}{|c|c|c|c|c|c|c|c|c|c|c|}
\hline & A. & $\mathbf{B}$ & C & D & $\mathbf{E}$ & $\mathbf{F}$ & $\mathbf{G}$ & H & 1 & $\mathbf{J}$ \\
\hline 1 & Potential TRU Waste & & & & & & & & & \\
\hline $\mathbf{z}$ & POSTIVE CLOSURE REQUUR & & $\ldots$ & ב & & & & & & \\
\hline $\mathbf{3}$ & & & & - & & $-C_{3}$ & & & & $-\infty-2$ \\
\hline 4 & & & $\ldots$ & - & & & $-\ldots$ & & & $-1-1$ \\
\hline$\frac{5}{6}$ & Nuintor of TRU Container A to & & - & $\cdots$ & & & 6876.52796990549 & & & - \\
\hline & & & & & & & & & & (- \\
\hline $\boldsymbol{8}$ & & EDE & & & & & & $2 \mathrm{hr} . \overline{\times \mathrm{a}}$ & GR & Ófisile dose \\
\hline $\mathbf{g}$ & & [romici] & $\mathrm{Cl}$ & Nem & CD & MiRF & Total ARF & {$[\min m \min 3]$} & Im33min] & [rem] \\
\hline & $u_{\mathrm{p}}$ & 520000000 & 100 & -68 & $=1 / 100$ & 0.1 & $0(0.001 \times 0.1)+(0.00000491024$ & 0.0000001 & 0.0228 & 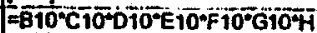 \\
\hline$\pi$ & Missile & 520000000 & 100 & $\overline{66}$ & 1 & $\overline{0.1}$ & $8(0.00140 .1)+\left(0.000004^{+124}\right.$ & 0.0000001 & 0.0228 & 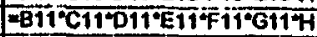 \\
\hline $\mathbf{Z}$ & Roll & 520000000 & 100 & EG & $\overline{0}$ & 0.1 & $(0.001-0.1)+(0.000004-1=24$ & 0.0000001 & 0.0228 & $=\mathrm{B12}^{\circ} \mathrm{C} 12^{\circ} \mathrm{D} 12^{-} \mathrm{E} 12^{\circ} \mathrm{F} 12^{\circ} \mathrm{G}^{\circ} \mathrm{H}$ \\
\hline & APC & 520000000 & 100 & -60 & 0 & 0.1 & $\left(0.001^{*} 0.1\right)+\left(0.00000^{*} q^{-22}\right.$ & 0.0000001 & 0.0228 & 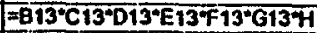 \\
\hline 74 & & & & & & & & & & ISUM(J10:J13) \\
\hline$\sqrt{5}$ & & & & & & & & & & \\
\hline 26 & Noles: & & & & & & & & & \\
\hline$\pi$ & & & & & & & & & & \\
\hline 18 & Formula sheet & & & & & & & & & \\
\hline 19 & of previous page & & & & & & & & & \\
\hline 20 & & & & & & & & & & \\
\hline
\end{tabular}




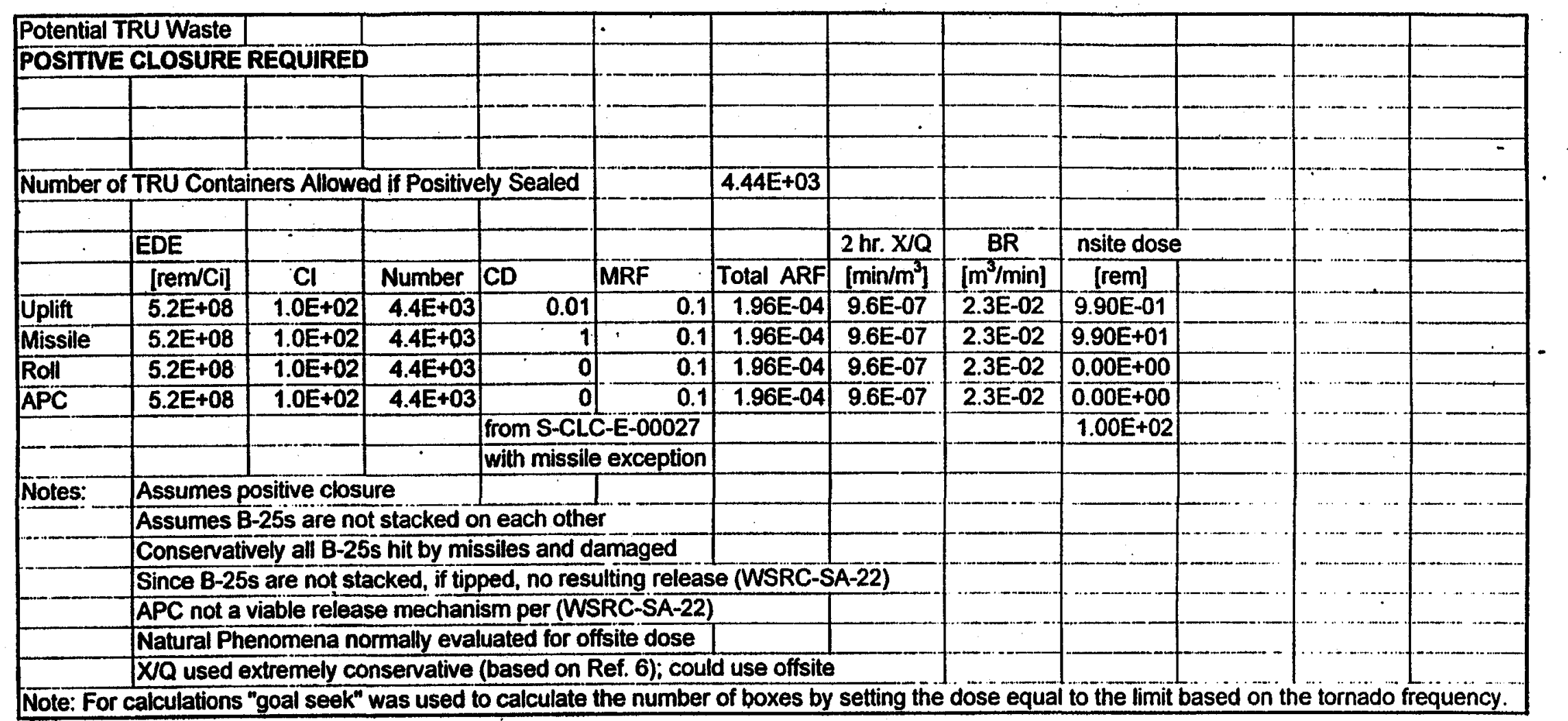


Attachment 7 - TRU Dose from a PC-3 Tornado, Onsite (CALC)

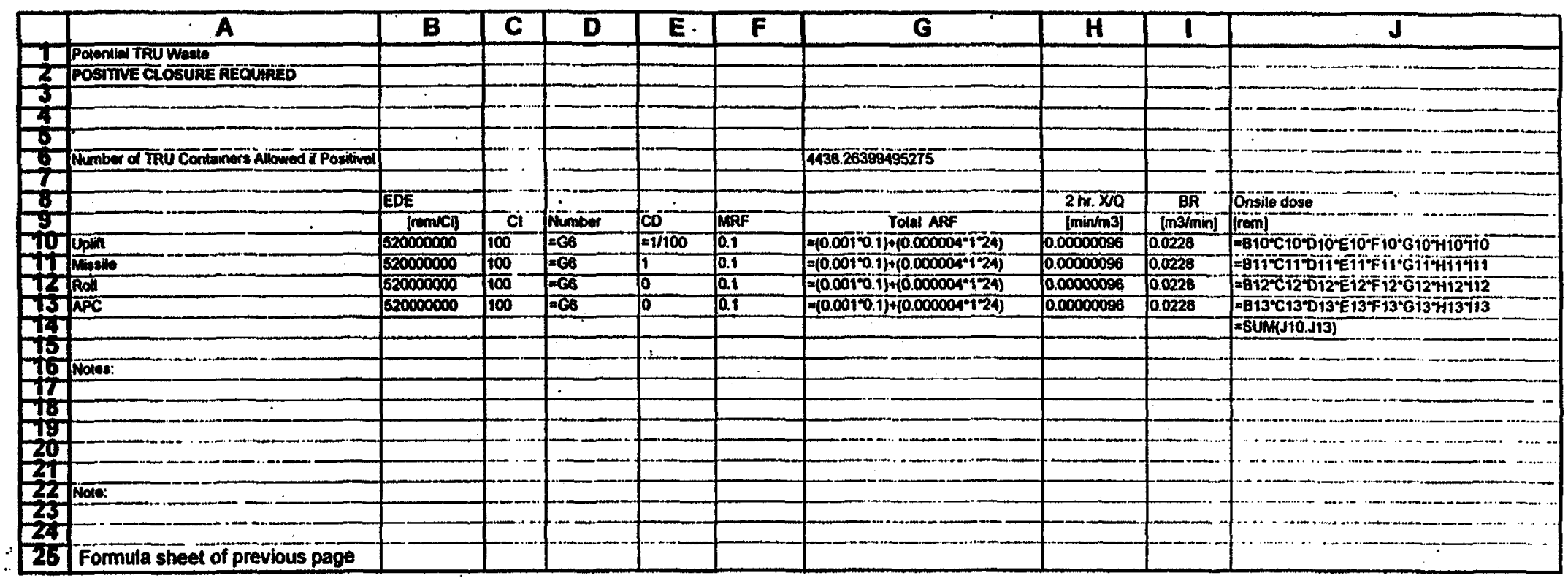

Page 24 


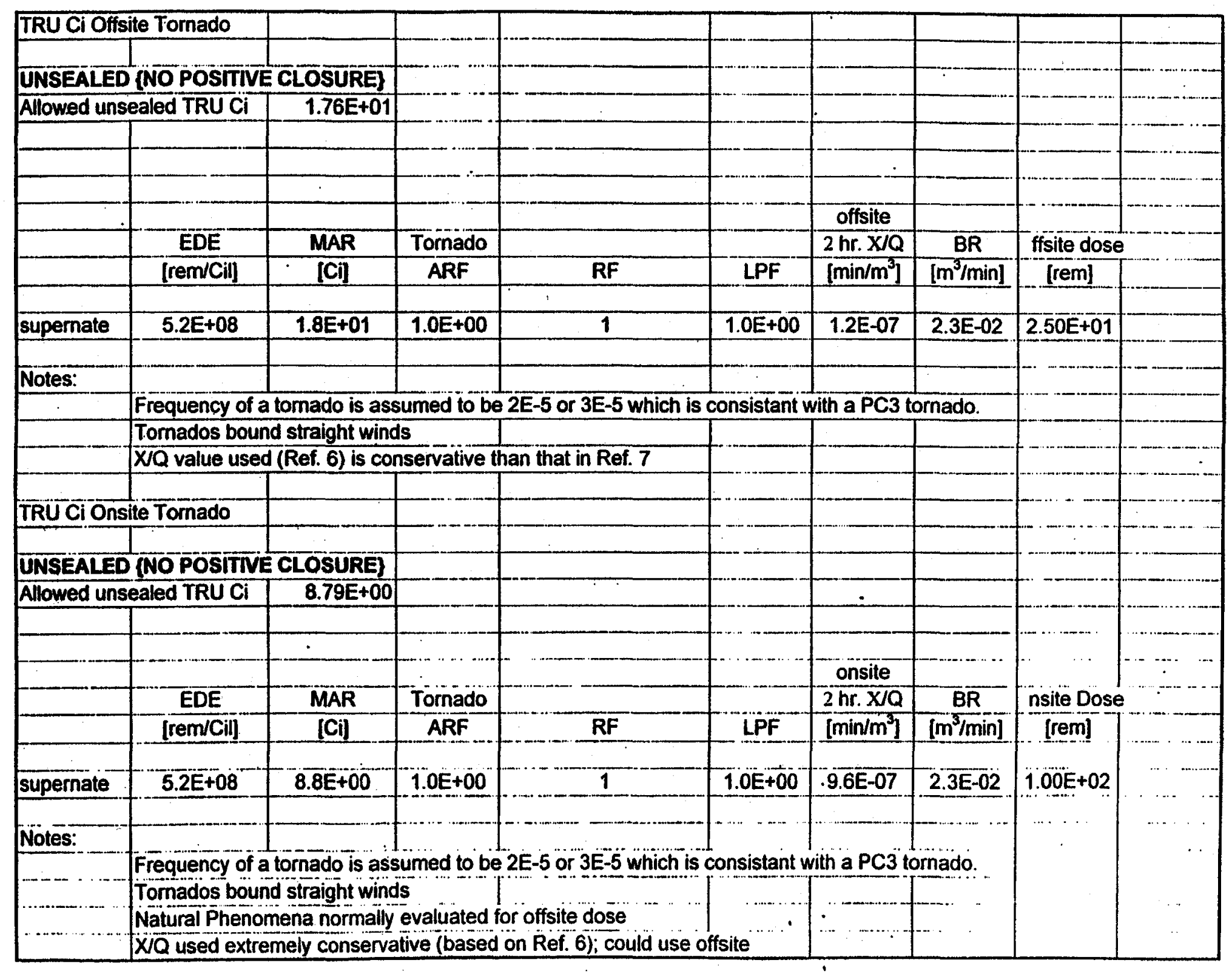


WSRC-TR-98-100050

Revision 0

February 10.1998

Attachment 9

Page 26 of 55

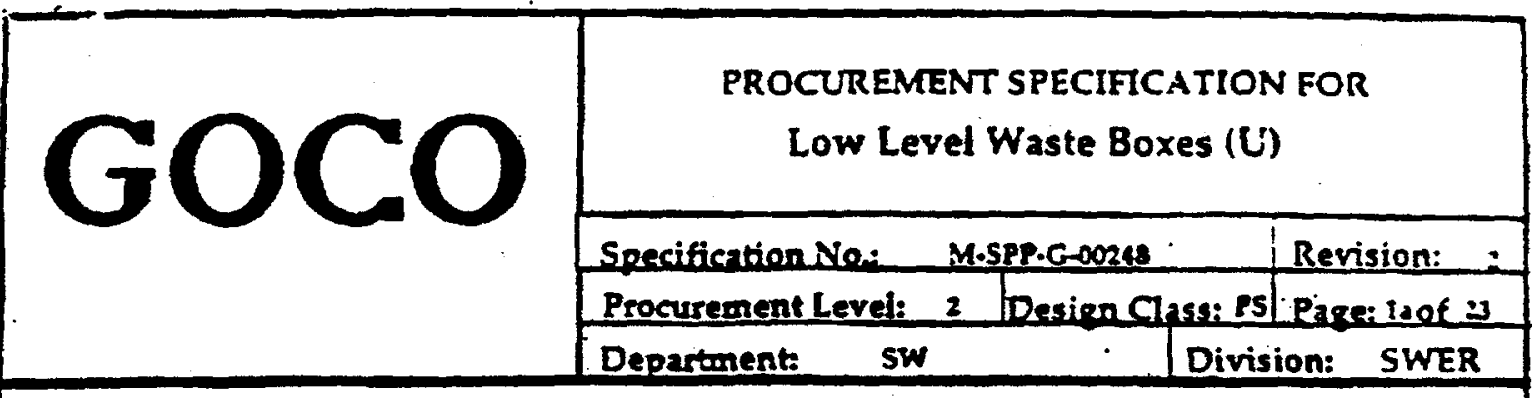 \\ INFORMATION ONLY}

Piopard by 1 BBS

Name V. B. Bhumbri, ros-3C

Title Senior Engines

Depe/section: Soltid Waterenpiacering

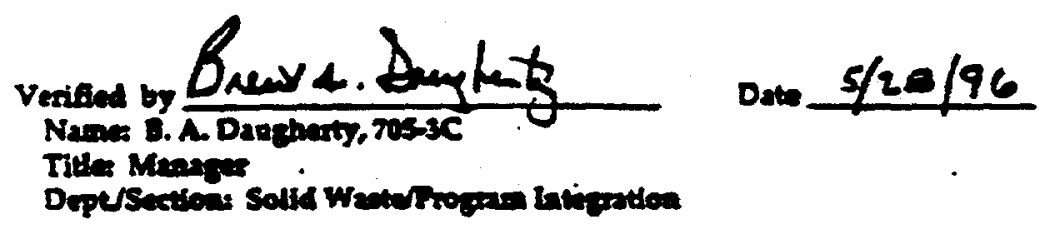

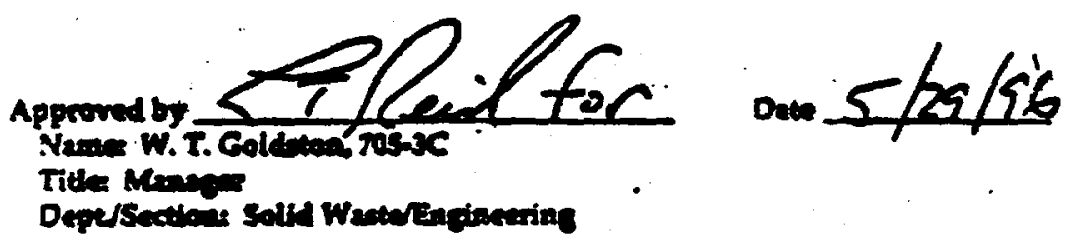

Daw 5.10 .96

Depelsection solld Wacterengiacering

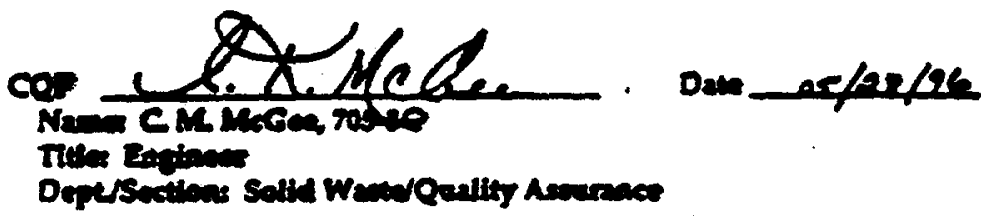

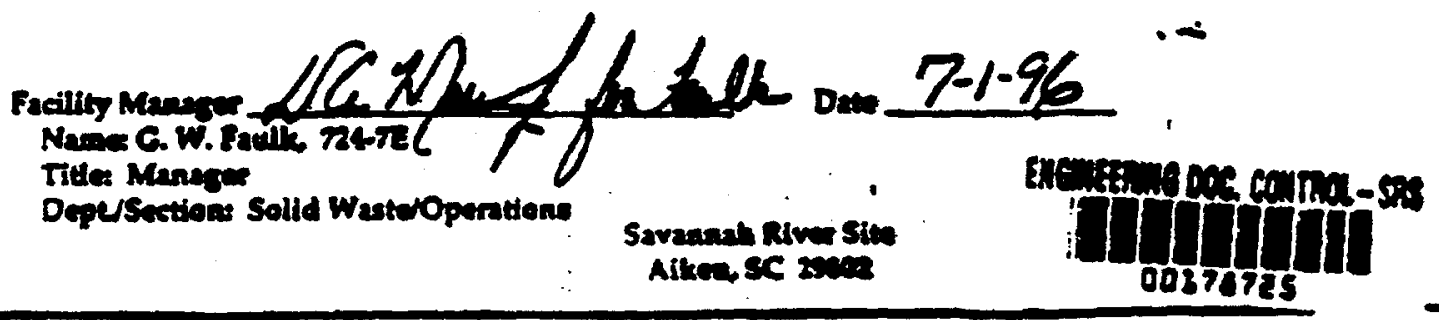


WSRC-TR- $48-1)(00 \leq 0$

Revision 0

February 10. 1998

Page 27 of 55

Attachment 9 (Continued)

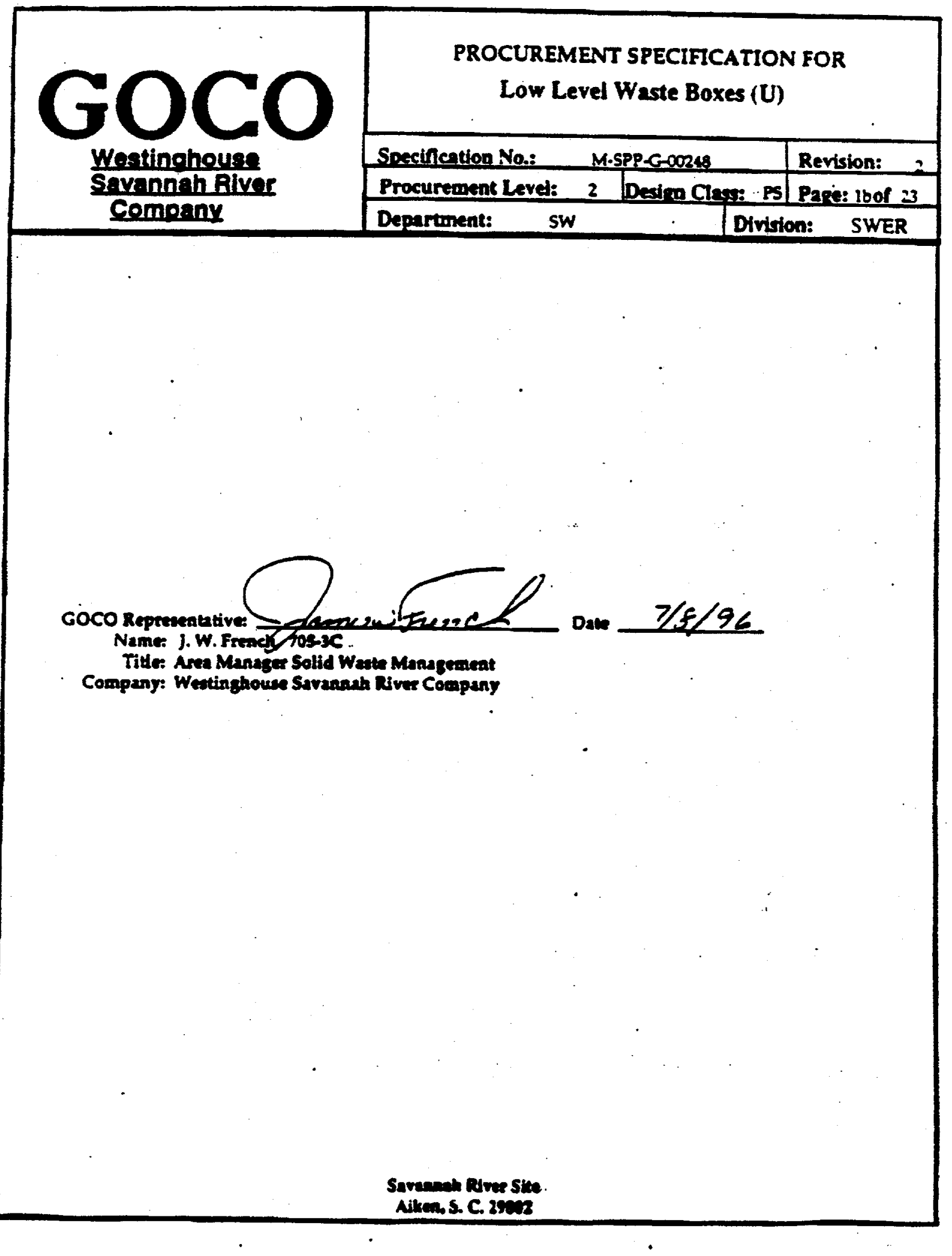


Attachment 9 (Continued)

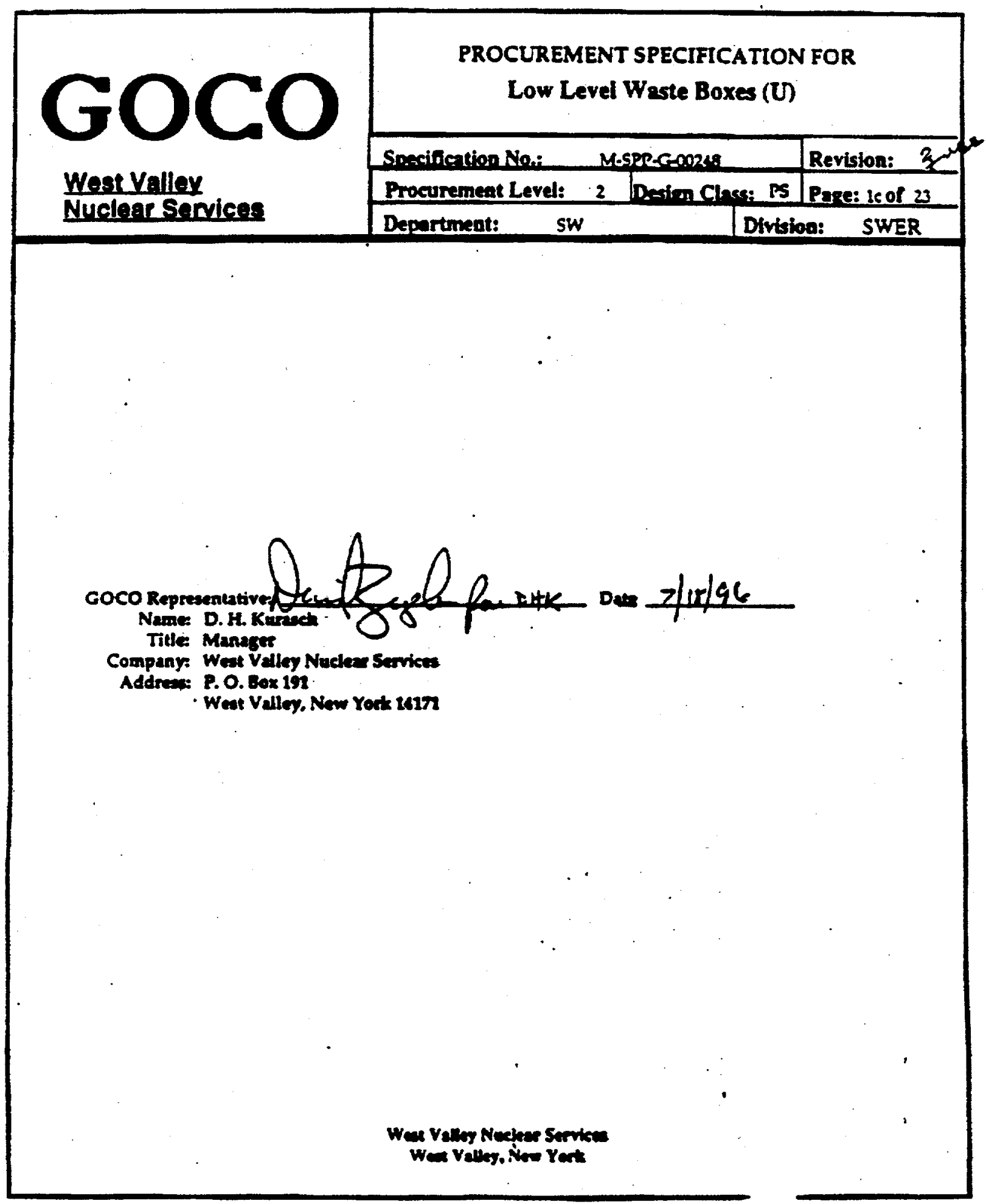


IISRC-TR-98-1)0050)

Revision 1$)$

February 10. 1948

Page 29 of 55

Attachment 9 (Continued)

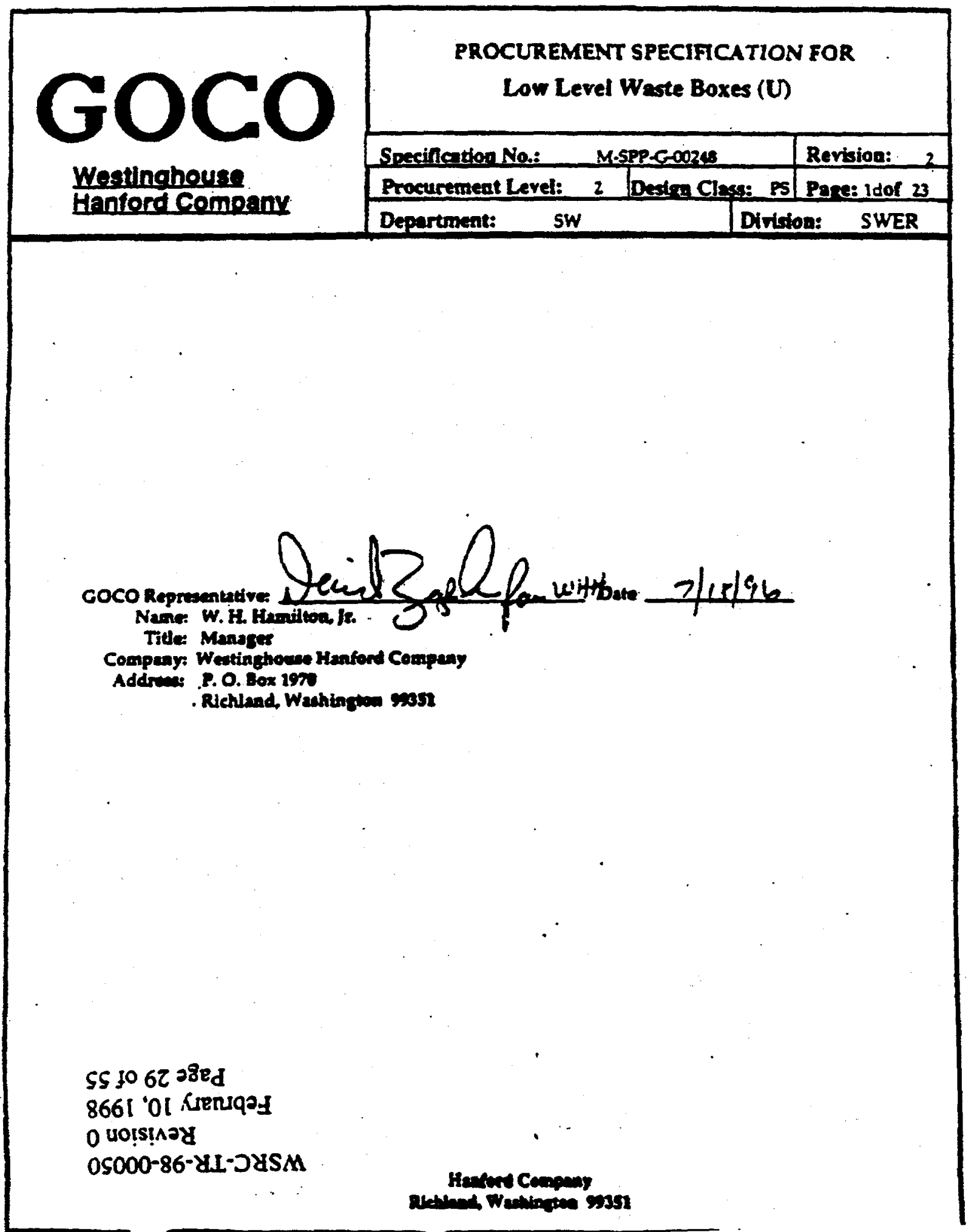


WSRC-TR-98-00050

Revision 0

February 10. 1998.

Page 30 of 55

\section{Attachment 9 (Continued)}

Procurement Specification for Low Level Waste Box
Specificanon No.: M-SPP.C-00248

Revision No.: 2

Page 2 of 23

Date: May 10, 1996

Table of Contuats

\begin{tabular}{|c|c|c|}
\hline Section & Title & Page \\
\hline 1.0 & Scope & 4 \\
\hline 1.1 & 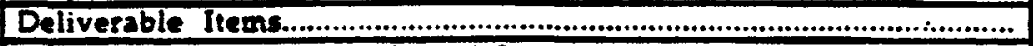 & 4 \\
\hline 12 & 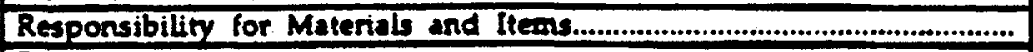 & 4 \\
\hline 1.3 & 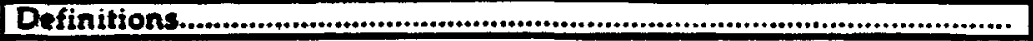 & 4 \\
\hline 2.0 & Service Conditions & $\mathbf{S}$ \\
\hline 3.0 & 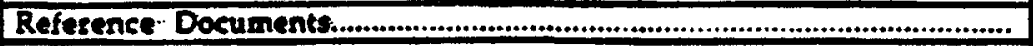 & $\mathbf{5}$ \\
\hline 4.0 & 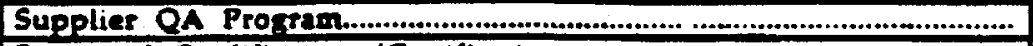 & 6 \\
\hline 5.0 & Personnel Qualificanong/Certifications...................................................... & 6 \\
\hline 6.0 & 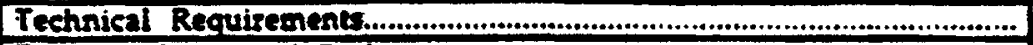 & 6 \\
\hline 6.1 & 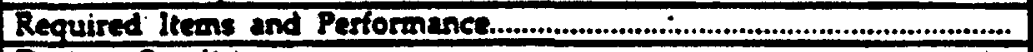 & 6 \\
\hline 62 & Design Conditions & 7 \\
\hline 6.3 & 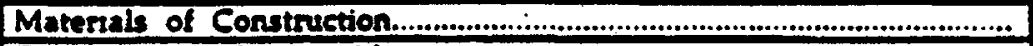 & 7 \\
\hline 6.4 & 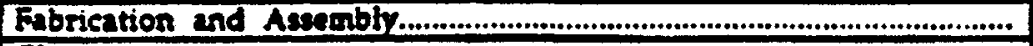 & 7 \\
\hline 6.5 & Cleenin & 8 \\
\hline 6.6 & 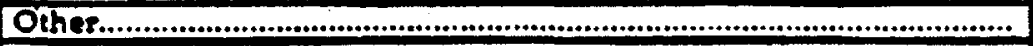 & 8 \\
\hline 7.0 & 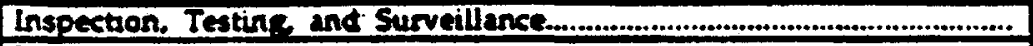 & 8 \\
\hline 71 & Inspectior. & 3 \\
\hline 72 & Testin & 10 \\
\hline 73 & Surveillenerean & 11 \\
\hline 7.4 & Final Acepetanse Medrods & 12 \\
\hline 8.0 & Instullation $\quad \cdots$ & 12 \\
\hline 9.0 & 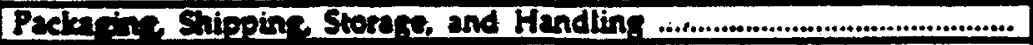 & 13 \\
\hline 10.0 & 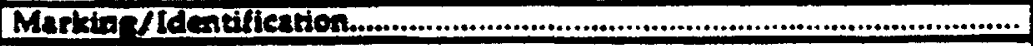 & 13 \\
\hline 11.0 & Supplies Desuruentation & 13 \\
\hline 11.1 & 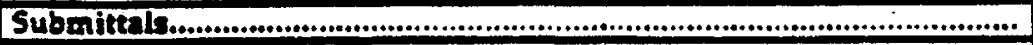 & 13 \\
\hline 112 & 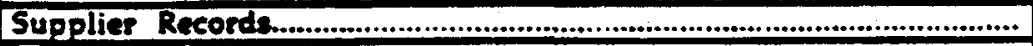 & 14 \\
\hline 12.0 & 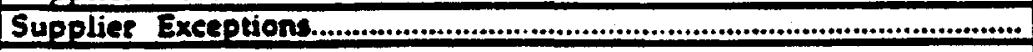 & 15 \\
\hline 13.0 & Attachments & 15 \\
\hline 13.1 & 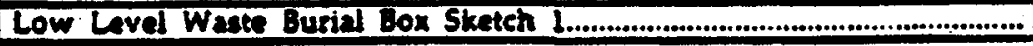 & 16 \\
\hline 132 & Options 1 thre $4 \ldots \ldots \ldots$ & 17 \\
\hline 133 & 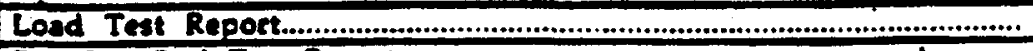 & 20 \\
\hline 13.4 & 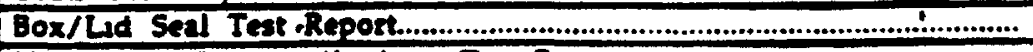 & 21 \\
\hline 13.5 & 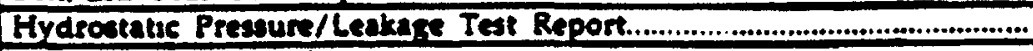 & 22 \\
\hline 13.6 & Recesvun: Luspection Report & 23 \\
\hline
\end{tabular}


WSRC-TR-9S-1)00 50

Revision 0)

February 10. 1998

Page 31 of 55

Attachment 9 (Continued)

Procurement Specification for

- Low Level Waste Box

Specufication Nio: M-SPP.G- -0248

Rension No.: ?

Page 3 of 23

Date: Mav 10. 1996

\section{SPECIFICATION FOR PROCUREMENT OF}

LOW LEVEI WASTE EOXES

Specifieation No. M-SPP-G-0pets

REVISIONS

\begin{tabular}{|c|c|c|c|}
\hline $\begin{array}{l}\text { Revision } \\
\text { Date }\end{array}$ & $\begin{array}{l}\text { Reviaion } \\
\text { Number }\end{array}$ & $\begin{array}{l}\text { Affected Sectione } \\
\text { and Paragrapbe }\end{array}$ & $\begin{array}{c}\text { Description of } \\
\text { Changes }\end{array}$ \\
\hline $5 / 10 / 96$ & 2 & 6.1 .2 & $\begin{array}{l}\text { Deleted the "sugsested mothod shall be to use } \\
\text { bands", in the second sentence. Deleted third } \\
\text { sentence. These statements had resulted in. } \\
\text { conhusion in the past with the requirements of the } \\
\text { paragraph. } \\
\text { Repleced "seding" by "closure" for consistensy. }\end{array}$ \\
\hline $5 / 10 / 96$ & 2 & 6.1 .5 & $\begin{array}{l}\text { Replaced "will by "shalle. } \\
\text { Deleted extrancous part of the note "-first before } \\
\text { - lifting hugs are used" }\end{array}$ \\
\hline $5 / 10 / 96$ & 2 & $\cdot \mathbf{7 . 2 . 1}$ & 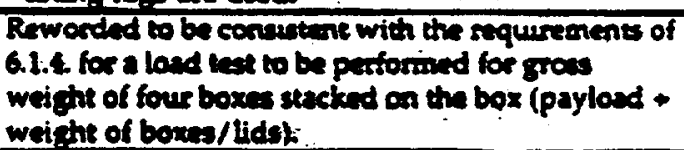 \\
\hline $5 / 10 / 96$ & 2 & 7.22 & $\begin{array}{l}\text { Delated the word "sugsested" from the second } \\
\text { sentence an it is in appropriate with the "shall" } \\
\text { requigement. }\end{array}$ \\
\hline $5 / 10 / 9$ & 2 & -11.21 & 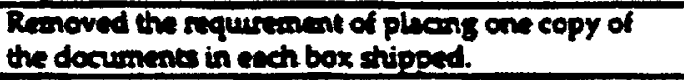 \\
\hline $5 / 10 / \%$ & 2 & 11.1 .2 & 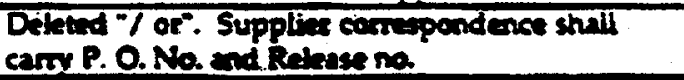 \\
\hline $5 / 10 / 96$ & 2 & Attedinent 13.3 & 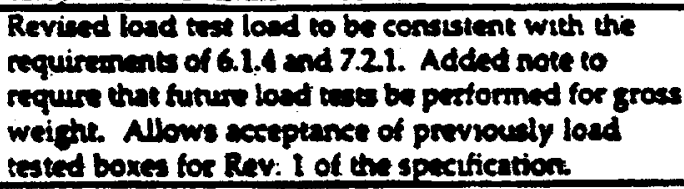 \\
\hline
\end{tabular}


WSRC-TR-98-00050

Revision 0

February 10. 1998

Attachment 9 (Continued)

Page 32 ot 55

Procurement Specification for Low Level Waste Box
Specatication No.: M-SPPC- 00248

Revision No.: 2

Page tof 23

Date: May 10, 1996

2.0 Scope

Design, fabricate, assemble and deliver strong-Hght (DOT Type 7A for Option 4) B-25 contauner boxes for storage packaging and transporting of Low Level. Solid, Radioactuve Waste of several COCO sites.

1.1 Deliverable Items

The supplier shall provide evidexce of compliance to this specification to the COCO Ste Ordering Boxes at the time of delivery. Stnct adherence to this spece is required to assure quality, relinbility and integrity of the boxes to prevent the possibility of spreading contanination during trasport or movement.

1.2 Reponsibilty for Materials and theme

The supplier shall be responsible for providing fabrication and rest procedures used to manufactures the Strong-Tight (DOT Type 7 A per Option 4) container specified heren. They shall also be responsible for fabercation and teting of the container while mantaining a level of quality comparable to the conditions specified in Section 40 over the entise life of the contract. As a minumum, yearly aidits shall be performed by one or all coco sites to venfy compliance. All materials ued in fabrication shall be certified new and unuend. The supplier will subrit drawing, prosedures, and test reports to the roleciaing COCO Site for approval prot to fabrication star.

\subsubsection{Responsibitity for Relesces}

WSRC COCO Site shall initiats the requisition. Spec. and award the contract. Subsequent releases of containes requests stull be through the individual point of ecatact(s) of each parneipating COCO Sile. Releases shall be 30 days priot to requind delivery date.

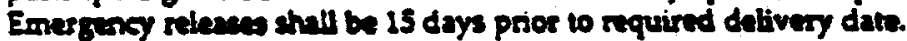

1.3 Deffrition

- AAC

- Ase

- AWS

- ASTM

- $c 00$

- HOLD PONT
After Award of Gontract.

American bstatute of Eted Construction.

AmericanWelding Society

American Society of Teoting and Materiale

Government Owned Contenstor Opurati.

A designated point in the manufecture of prosening of an item beyond which actuvities muy not continus without the prisience of inspection of survedlance persornet. 
WSRC-TR-98.1)00 50

Revision 0

February 10, 1998

Page 33 of 55

Attachment 9 (Continued)

Procurement Specifieation for. Low Level Waste Box
Specuficazon No.: M-SPP.G-00248

Revision No.: 2

Page 3 of 23

Date: May 10. 1996

- ICQR Independently Sontracted Quality Bepresentatıve.

- LOT A negotiated point between each representative and the vendor whuch is descriptive of a break in the fabncation/delivery process for boxes to identufy a quantity of boxes for QA purposes. i.e.e either based on the materials of fabncation. the vendor's approved process or the number of boxes transported in each tructload, elc.

- SWE Solid Wuth Engineering.

- WITNESS POWT A desigiated pount in the manufacturing of procesuing of an item which requires the suppliee to notify the ICQR suffiesently in advance to allow for scheduling and pesformance of witnes test activiters. The witnes point mube waved by the desiganed representanve providing the activity can be witnessed on future rure of matresal and the ICQR neviews the documentation for the previous activity.

- WSRC Westunghouse Savanah Biver Goopany.

\subsection{Servia Condition}

These boxes are to be used for the packagire, ranspont and storage of low-level solid, radioactive waste (with not mote than one percent (1\%) liqud by weight) geneented at each of the COCO sites.

\subsection{Refintenes Document}

The supplier shall ensure that the boxes onect the following sodes and seandards.

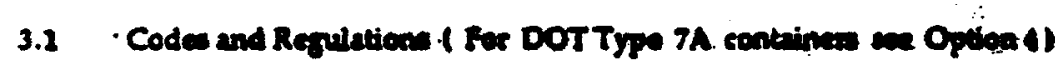

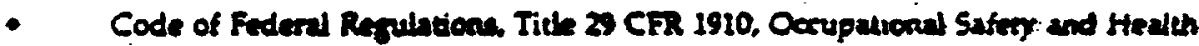
Standards . 1990 revition.

Code of Fuderal Regulacions. Title 49 CFR 173.21. Standard Requureonents for All Pactagang. 1990 rvivicen

Code of Foderal Regulatons Title 49 CFR 173.41. Cenerd Design Requirements for AU Packagine 1990 revivion.

\subsection{Standards}

- ASTM A.S69, stert cabon (0.15\%) hot-rolled, shout and strmp, commereial quality. "i987 Dook of ASTM Standards".

- ASTM D-103673, Specuication for Fexible Cellula Materials - Spongs or Expanded Rubber." "1975 Book of ASTM Sandards".

- AWS Di.1-90. Strucrural Welding Code - Steel.

- . ASTM D-1684, Type 1. Pant Finich Cnteria, "1987 Book of ASTM Standands". 
- NSC, American Institute of Steel Constructon Handbook.

- ASTM A-36, Specification for Structural Grade Carbon Steel. "1987 Book of ASTM Standards".

\section{3}

\section{SRS Documeats}

Savannah River Site Sketch (Altachment 13.1)

Reference Sketch:

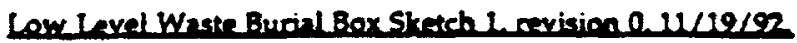

Note: The qualifying vendor thall submit box detail designs or drawinge aswating fabrieation and inopection procedune for approval by participating COCO. The attached sketeh and Options Page are

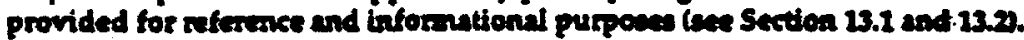

\subsection{Supplier QA Prognen}

THESE CONTARERS WML $8 E$ PURCHASED AS A LEVI 2 PROCLREMENT. TheY will be required to meet all requirements un Sections 3.1, 32, and 3.3. In addition these packages shall be trspected, at the facilty, by an ICQR as noted here within this spacticaton.

\subsection{Personnel Qualificationekentifieatione}

Personnel partorming activities shall be qualified or certified in accondance with the supplier's approvad Quality Ascurance Progran. Weldes shat be qualified per Section $V$ of

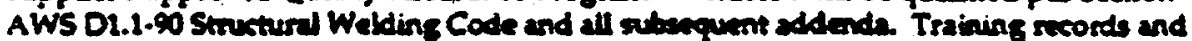
certificabon shall be thinteined by the vendor for all personnd to desmonsrate thets

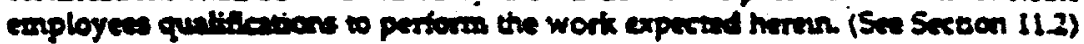

6.0

\section{Trenent Raguiranat}

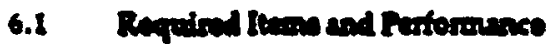

6.1.1 The vender shall submit box dengn for approval to the releseng Coco site. Attachument 13.1 is provided for information and nference.

6.12 Provisions shall be ande to ensure fath positive clocure of tha lid to the box. The closure mechanuen shall echieve twenty percint munumum compression of the gasket between the lid and box after closur. It is the neponsibility of the vendor to identafy these methods and pesent their finding for consideration to each of partipipating facilities. The vendor's lid/box closure desion shall be submitud for approval to all. sites. The closure mechanism shall not interfers wath the bos stacking capplotites. The lid/box dosure mechanisan shall be one of the iturs to be approved by COCO.

6.1.3 Each box shall huve capecity of holding five-thousend pounds (5.000 lbs) of solud wate (with not more than one persent (IX) liguad by werehts 
WSRC-TR-98.00050

Revision 0

Attachment 9 (Continued)

February 10. 1998

Page 35 of 55

Procurement Specification for

Specification No.. M-SPP.G.00248

Low Level Waste Box

Revision No.: 2

Page 7 of 23

Date: May :0..1996

6.1.4 Each box stall be capable of being stacked five (5) high. The bottoen box shall support 20.000 pounds payload plus box/lid weignt with ounumal dustostion of the sidewail.

6.1.5 Each box shall be configured to allow for complate manpulation of the box with a forktruck. The lidshall be costiguned in allow lifone of the lid oif the box by hand. Both contigurations shall not interfere with the stacking capabilutes of the box.

Note: Removable eyes and/or lifting lug chall not be considend as a viable altemative to andipulate these boxes in this poeificaten. If a crane is sequireds epreader bas, slinger wire straps, ete, shall be considered.

6.1.6 Optrons are in Section 13.2 Supplier to provide optional design upon Coco ste Release.

6.1.7 A minimum dy film thickness of 2.6 orils (.0026 inches) shall be provided on the outer surfaces of all boxes. The finish coating shall comply with ASTM D-1684. Type I standards. Colors shall be identified on Option I Section 13.2:

6.2 Daigen Condition

Other than the conditions mentioned in Sections 3.0, 6.1.1 and 13.1. no special design conditons shall exust due to internal differences between each of the participating GOCO.

6.3 Materials of Coantroction

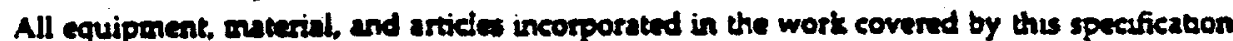
shall be new and unused. Other than what is mentoned in Sections 3.0. 6.1.1 and 13.1. all materials shill be frese from defects that would adversely affect the performance or maintainability of individual components ecroes the overall asceonbly of this box. Maternls not specified hevin shall be of the sanse quality a materats used for the intended pupese in sommercial prection.

6.4 Faldication and Amoby

Other then what is requested in the specification, all standard methods or practuces used to fabricute these boxes by the approved supplief inall be aceepeable:

\subsubsection{Stoul Fabrieation}

The sted ued shall be fres from kinks, shap bends, and other conditions that wouid be deleterione to the finched product. The manufecturing procesese shall not neduce the strength of the stevel wo value lese than untended by the desiger The ananufacturing proces shall be neat and accurat. All bends thall be made by controlled mens to ensure unuformuty of size and shape.

\subsubsection{Bolvad Connections}

Bolt holes shall be aceurately punched or drilled, with all burrs nenoved. Washers or lock washef's shall be provided an ecrordance with good commerval practices. All

$\because$ nut and serrws installat on the bos shall be tight. All bose bolts. nuts and serews be boxed and placed insude the box for future use 
WSRC-TR-98-1000ミ0

Revision 0

Attachment 9 (Continued)

February 10. 1998

Page 36 of 55

Procurement Specification for

Specufication No.: M-SPP.C.00248

Low Level Waste Box

Revision No.: 2

Page 8 of 23

Date: May 10. 1996

\subsubsection{Riveted Comnection}

Rivet holes shall be accuntely punched or drilled, with all burs removed. Ruvets shall be driven with pressure tools and shall complerely fill the holes they were intend for. When not countersunk or flattened. all rives heads shall have the approptsate shape and size intended for a rivet. Rivet heads shall be full, neatly made. concentric with the rivet holes, and in full contakt with the surface of the nember it is holding together.

\subsubsection{Weldins}

Welding procedures shall be in aceordance with AWS D.1.1-90. Structural Welding Code and all subsequent addenda. The surace of part to be welded shill be tree from rust, scale, paint, greace, or other foretgn matues. Welds shall be of sulficent suze and shape to develop the full stength of the parts cornected by. the weid. Weids shall tranemit stese whthout permanent deformation or failure when the pars connected by the weld ase subjected to proof and service loeding.

6.5 Qeening

The standard cleaning practices uned by the approved suppliet shall be acceptable.

6.6 Othes

All boxes shall be of standard quality wortonanship consintent with industry-wide praceces free from internal and extenal imperfections detrionental to their intended use.

7.0 Inspection, Teding and Survillace

7.1 Inpoution

7.L1 It shall be the vendor's responsibulity through thair own adaninistrative control systeren, to pertiorm inepactions neceseary to assurs conformance with the specticanon.

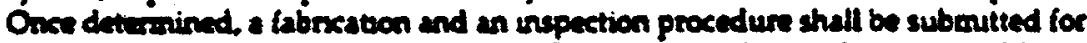
approval by all participating fecilities. Onee approved, any changes shall be suberitud, in writug by the vendor to each representative foe disposition. Wntten approval must be given prot to implementawon of any changes. 
7.1.2 Non-conforming :tems shall be identified and segregated (when practical) by the supplier or subtier supplier. A SDDR shall be writen for each box dispostuoned useas-is" or "repar" and submutted to the appropriate facility placeng the order for approval. A copy of the approved SDDR accompany the box when if is shipped to the requesting site. It is the responsibility of the vendor to ascure that each site placung an order epproves the SOOR(s) for "use-as-is" or "repair" boxes mithun that order.

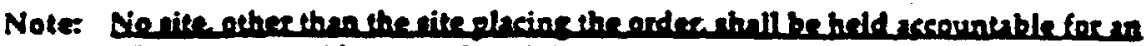 SDDR noprosed byenterhersite.}

7.1.3 Each COCO shall reserve the right to have access to the supplier's facilitea. uncluding ther subtiar suppliers, vendors and subcontractors tacility for the purpose of seview, audit, surveillance, witnessing inspection, and teateng activities.

7.1.4 Each GOCO shall reserve the righi to perform inspations and/or survellance of manufactured products being made during fabrication, asembly and sesting. The ICQR shall review and perform checks to venfy that the boxes have been manufacturnd in accordasce with the approved procedure.

Note: No site shall have the authority to change, alter or aodify any materials. procederen, or contrestle) grencrived for this purchase without approval of all cibes. If any ait want to popose s change, the appropriake representative

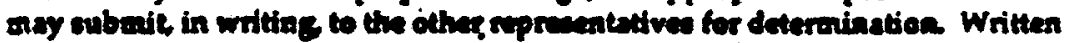
appowal of the change to the vender nus be twoived frow all giteo prior to impleanention.

7.1.5 The following requirements shall be witnesed by the ICQR and/or COCO representative during each visit to the vendor for inspetion seascoses

- Vetify by review of documentaton that weldess and procedures used were qualified pee AWSO 1.1.90 Section V.

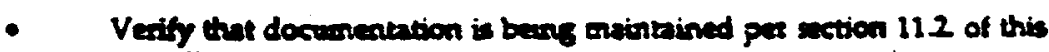
specifiention.

- Chest the boxes foe guneral dimensions and trial fit of the lid.

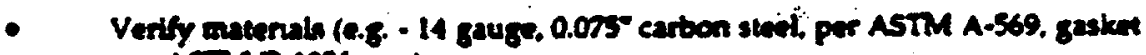
per ASTM D-10S4, ete.).

- Inspect bos enterior for distortions greater than two inches (2).

- Verity that shap edges and burn are renoved from the interior and exterior of the box, lid. and lid handles.

- Review surface preparation and painting requismants Bain/primer shall have a unitorm cover over the entire box surtace.

- Revrew the sealing whnique and effectivemess 
Procurement Specafieation for Low Level Wate Box
Specufication No.: M.SPP-G-00248

Revision No.. 2

Page 10 of 23

Date: May 10. 1996

- Check the boxes to assure that the lid can be removed without the gasket maternal adherung to the box rm. Neither lid. box. nm, nor gasket matenal shall show damage durng the procedure.

7.2 Testing

7.2.1 The supplies shall be required to perform at least one uniform load test per box desizon. For safety reacons, the suppliee shall nove the box to an indepandent testing area This test shall be witnessed by the ICQR and/or COCO representrtive requesting the box for suthenticity.

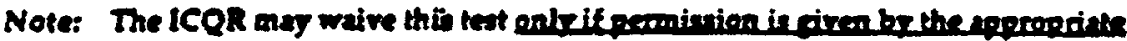

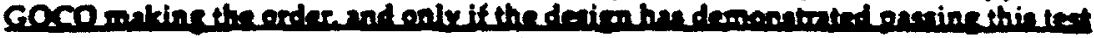

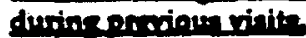

A test procedure shall be provided by the supplies to demonstente that a box, half full of sand or water is capable of supporting a uniform land of wrenty-thousand pounds plus box/lid weight of four boxes $(20,000+4 x-500=2,000 \pm 300$ ba) on the wop surface (tsd) of the box for a mininum of fous hous (4 has 25 win) with lese than three-eghth inch $(0.325 \neq 0.125)$ deformation in the side walle. Mis procedure shall be subuitted. in writing and appeoved by the ordering ste prior to use. As a minumum the results of this procudure shall be documented in a stoper tibled Low Loved Wast Burial Box Lad Test Report" with key mitress points provided (see Attechenent 13.3). The supplier onay choose to use his own form, but shill use as menimum the dats shown in the attachuentin.

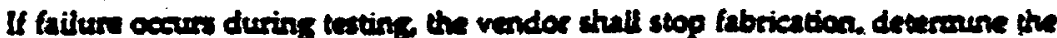

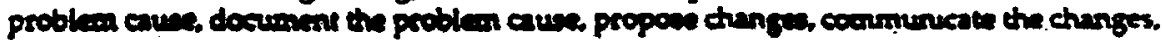

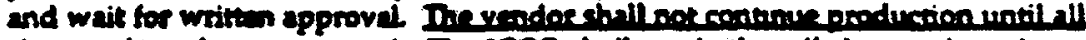

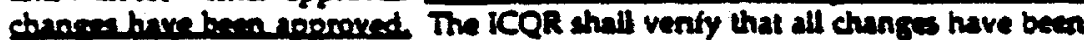

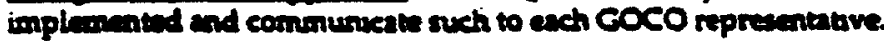

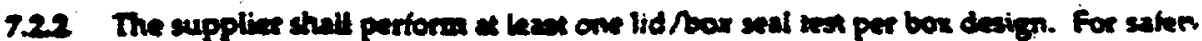

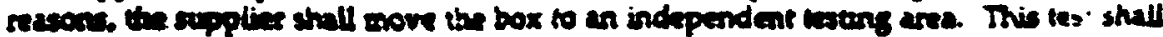

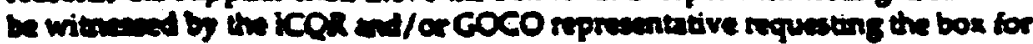
autheadicity.

A tese procedure shall be provided by the supplies to dencentent a fact cusitive sealing approxh. A gacket comprasion of twenty persent minimum shal! - echueved. This procodure shall be sebsoittud, in writing and approved by COCO ie ssee proor to use The ICQR shilf be enponvend to perfocen the teat as they dewin n .eseary, with

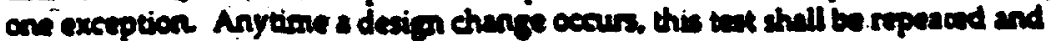
wituresed by the ICQR automatiedly.

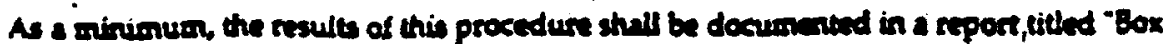
Lid Seal Test Report' with key witness point provided (ses Attachment 13.4). The

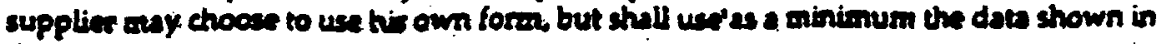
the attachanent.

If failure ocours durng wating, the vendor shall stop fabrication, deverwine the 
WSRC-TR-98-0000 $\leq 0$

Attachment 9 (Continued)

Revision 0

February 10, 1998

Page 39 oi 55

Procureenent Specificatien for Low Level Wate Box
Spectication No.: M.SPP.C-00248

Revision No:: 2

Page 1: of 23

Date: Mav 10, 1996

problem cause, document the problem cause. propose changes. communicate the charges. and wast for written approval. The yendorshall not eontonue productoen wath ail changes haye been appeoved. The ICQR shall verfy that all changes have been unpleanented and communcate such to each representative.

7.2.3 The vendor shall perform a sanding water test on five percent (5\%) of each lot of the boxes manufactured. This that sthall be witneseed by the ICQR and/or COCO representative requesting the box. The boxes bated shall be chosen by random pick For safoty resons, the suppliet shall move the boxes to an undependent testing area. The test shall be no longer than four hours ( 4 hrs \pm 5 minutes) in duration. The test shall cause the box to be filled to within ore unch (17) from the top of the box with water. No leaks shall be peronitted. If leaks are found, ten porcent i106) of the boxes within that lot shall be tested. If any leaks ar found in the 10\%, then 100\% of the boxes in that lot will be tested. Any leaking boxes shall be repared and retested by the vendor at no-chnge. The vendor's ret procedure shall be suberutted for review and approval of all sites.

As a minimum, the realts of this test shall be documented in a repont ritled "Hydrostatic Preseure/Lakage Teat Report" with by witness points provided (see Attachment 13.5). The aupplier any choose to use his own form, but shall use as a minimum the data shown in the altachment.

If failure occurs during teating the vendor shall stop fabrication detwenune the problem cause, document the problen cause, propose changes. communicate the changes. and wais for written approval. The yendor shall not continue production und all changes huve be. anpenged The KQR shall verfy that all changes have been implemented and communieatia such to exch rupresenutive.

7.2. Before shiponent of boxes is made, the ICOR and/Or COCO REP shall inspect and winese teseng of all boxes for accoptance af the vendor sute. Acerptance shall be based

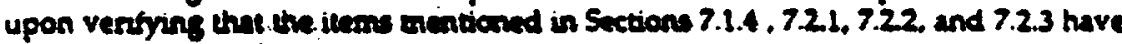
bean couplatid and signied.

Note: It is the ropenability of the vendor to coordinate a echedule whereby the ICQN ainiaines trips to the vendor's tacillity.

725. Within finen (b) dars of his vait to the vendors sits, the KCQR and/or COCO REP shatf iswe a unewo stating whather acceptance has been granted per the unspectons and ceats epecified in Secton 7.1.7, 7.2.1., 7.22 and 7.2.3.

\subsection{Surveillance}

7.3.1 The supplier shall nothy the Soss. (Supplier Quatioy Surveillance Services) group no

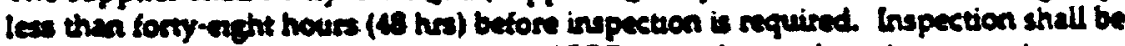
performed by the KCQR Every time the KCQR vints the vendors site, a a minumum the ICQR shall withess Sechon 7.1.4 and perform the following.

Notes Any Goco shall nearve the right to waive inopection on their portion of this

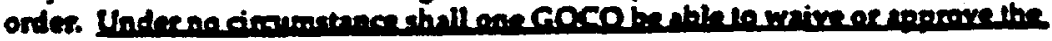
inentinn of and the foce. 
Procurement Specification for Low Level Waste Box
Specufication No.: M-SPP.G-00248

Revision No.: 2

Page 12 of 23

Date: May 10. :996

- The ICQR and/or GOCO REP shall pick and witness the uniform load rest ! see Section 7.21). After the inspection is complete. the ICQR or GOCO RER strall review and intial key points on the Low Level Waste Burial Box Load Test Report. This report shall be subruked as documentition per Section 11.0 of this specification.

- The ICQR and/or COCO REP shall pield and witness the box/lid seal test (see Section 7.2.2). After the inspection is complete, the LCQR or COCO REP shall review and initial key points on the Box / Lid Seal Teat Report. This report shall be submittad as docimentation per Section 18.0 of thes specification.

- The ICQR and/or COCO REP shall pick and witnese the hydrostatic leak test of as a minimum at least five pereent (5\%) of each bt of boxes manufactured (ste Section 7.2.3). Afrex the inspection is coenplete the KCQR or COCO REP shall seview and initial key pounts on the Hydrosate Prasure/Leakage Test Report. This report shall be suberutted as documentation per Section 11.0 of thes specification.

7.3.2 Inspection results shall be documented by the vendor and sifined by the ICQR The inspection results shall list the identification number of the box unspected. The supplier shall maintain a copy of the ICQR sigend inspection repore whth the quality assurance documentation as-well-as include a copy of the rport with each shipinert.

7.3.3 Individuals as authorised by GOCO. shall have aceess to the vendor's factity or area where the contrected services are in procese. This accusiblity requirement is also applienble to ste vendor's subtier supplies when he contrects the services of others to

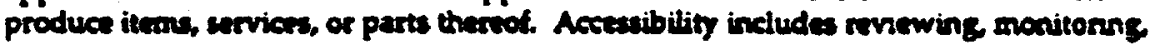
and auditing of contrected in-process work induding asecentud documentsuon

7.3.4 Any iven which does not onet this specifieaten shall be replaced by the manufacturer tree of charge.

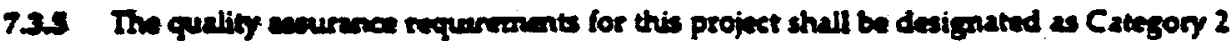
per QAP 7-1 of the Quality Asaurance Manual (WSRC - 10). This eatepony is where the ICQh and/or his sepresentabve shall witnes and venty all functional teating of the equiponent at the manufacturer's facility before the equponent is released for shipanert.

\subsection{Final Acesptance Methoda}

7.4.1 Final seceptance of equipment shall be beend upon the satialsctory completion of the "Receiveng Instructions For Inspection" (ses Section 13.6). Nen-conforming itean(s)

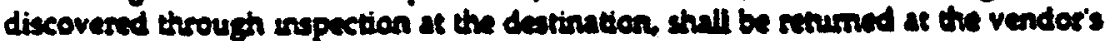
experse unkes written a getement is mesived troen the COCO nquestung the shupment to "accept-ac-is" or unless agrement is made whentby the vendor shall be pemuted to repar the ttem at the COCO.

8.0 Installation

Not Applicable 
Procurement Specification for Low Level Watte Box
Specificaton No.: M.SPP.C-00248

Revision No.: 2

Page 13 of 23

Date: May 10, 1996

9.1 The packaging, shipping, storage, and handling shall be designated as Level D. per WSRC/COCO standards. The supplier shall be responsuble for meeting all Level D requirements. Level $D$ requirements shall be as shown below:

9.1.1 Prior to packagung an item. dirt, oil residue, water. metal chips, of other forms of contaminates shall be removed.

9.1.2 Items shall be properly packaged in contatners, erates or other means as appropriate. All loow jtems shall be boxed. biocked, anchored, braced, and cishioned to prevent physical damage. In addition itens shall be stored on cobbing dinnage of pallets for at circulation and to svord trappeng water.

9.1.3 These boxes may be stond outcoos in a well draned area.

9.2 The boxes shull ant be shipped without approval of the representative. The vendor shall be held responsible for notifying the appropriate representative at least ten (10) busuness days prior to the shipenent date.

9.3 Final Shipanent of all the boxes and documentation shall be identified on the purchase order.

\subsection{Markinghdentifiention}

Each box shall be uniquely identried by providing the following information on a secure. durable. steel ag(s) welded in the uppes nght comer of the long nde of the box or by stenciling with paunt. (Noter

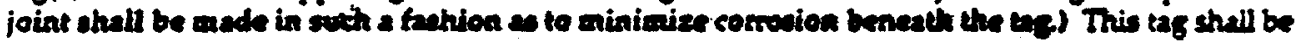
prepared and paunted in the sane fachion a box. Any stenceling ande on the box shall be with paunt of contrasting color and shall be compatible with the exterior box final protective conting:

- Relesse number. and numbating saquence for the contrines (for example. KO123436-02. indiesting the second box of order Fo(12356):

- The following shall be stenciled on both long sides of the box on the upper 2/3 per the attached

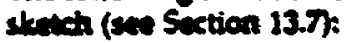

\begin{tabular}{|c|c|}
\hline $\begin{array}{l}\text { Empty Weight } \\
\text { Valumi } \\
\text { Pay Loud } \\
\text { Total Cross Wt. }\end{array}$ & $\begin{array}{l}\text { (for exringle, } 350 \mathrm{bs} \text { ) } \\
\text { (for example, } 90 \mathrm{f}^{3} \text { ) } \\
\text { (for example; } 5000 \text { lbs.) } \\
\text { (for example, } 5350 \text { los.) }\end{array}$ \\
\hline
\end{tabular}

\subsection{Supplier Decuminitation}

11.2 Subaittals

11.1. The vendor shall prepare two (2) complete sits of documentation for each shipment of boxes. One set shall be placed in the vendecis qualiby asournace fikes. and another set shall be placed un an envelope marked Receipt inspention Donumentanon:. Each shee shall list the purchase order number and pince numbess for identifieation. Each set shall contain a document unventory transwutral show (lishng all documents and number of pages arrached) and ane or more of the attuchad documentes 
WSRC-TR-98-1)00 50

Revision 0

Attachment 9 (Continued)

February 10. 1998

Page +2 or 55

Procsirement Soccification for

Low Level Waste Box

Specification No.: M.SPP-G-D0248

Revision No.: 2

Page 14 of 23

Date: May 10. 1996

- A cernficate of conformance signed by an exerutive officer of the supplier (referencing that the box is a strong bight contavier per 49 CFR 173).

- The Low Level Waste Box Load Test Repors or equivalent rutaled by the ICQR.

- The Box/Lid Seal Test Report or equivalent initialed by the ICQR.

- The Hydrostatic Pressure/ Leakage Test Report or equivalent initaled by the ICQR.

11.1.2 All correpondence ahall cary the followng references:

- Purches Order Number and selease mumber.

- Projest No. COCOI

\subsection{Supplier Reconds}

11.21 The following records geananted in asocianon with this specification, shall be maintained by the vendos in an Underwriter's Labontory approved fire resictant safe of fire resistant locking tite cabinet foe the length of contract plus any extensions.

- A copy of this specifieation with any sunsions and the awarded conoact with any revisions.

- Any approvid non-conformance reports for:

- Incoring nw materiale.

- Finished products.

- Instrumentation.

- Proceduse devivions

- Product deviationa

- Any cornectuve acson reports.

- Any procedures used to labrieate, inspect, and fect.

- A quality ascurance manual documanting the vendors quality asurance progens.

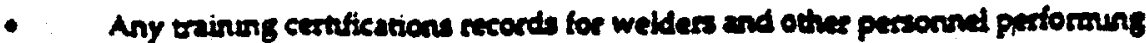
sntical functions affectung product quality.

- Any documertation generated that eertifies product quality. L.e., material mill teat reporrs, ete. 
WSRC-TR-98-1)0050

Revision 0

February 10.1998

Procurement Specification for Low Level Wasta Box

\section{Attachment 9 (Continued)}

\section{Page +3 of 55}

Revision Nio.: 2

Page 15 of 23

Date: May 10. 1996

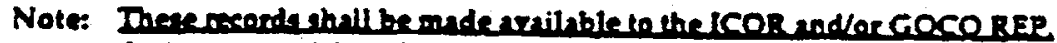

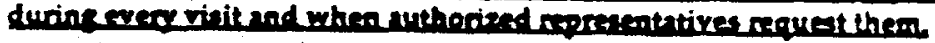

12.0. Supplier Exceptions

Not Applieable

13.0 Attachments

13.1 Sketch 1. Revision 0 of the Low Level Wate Burial Box

$13.2^{\circ}$ Options 1 thru 4 ( 3 pages)

13.3 Low Level Waste Burial Box Load Test Report

13.4 Box/Lid Seal Test Report

13.5 Hydronte Presure/ Leakage Test Report

13.6 Receiving Instructions for Inspextion of thi B-25 Type Boxes 
WSRC-TR-98-00050

Revision 0

Attachment 9 (Continued)

February 10.1998

Page +4 of 55

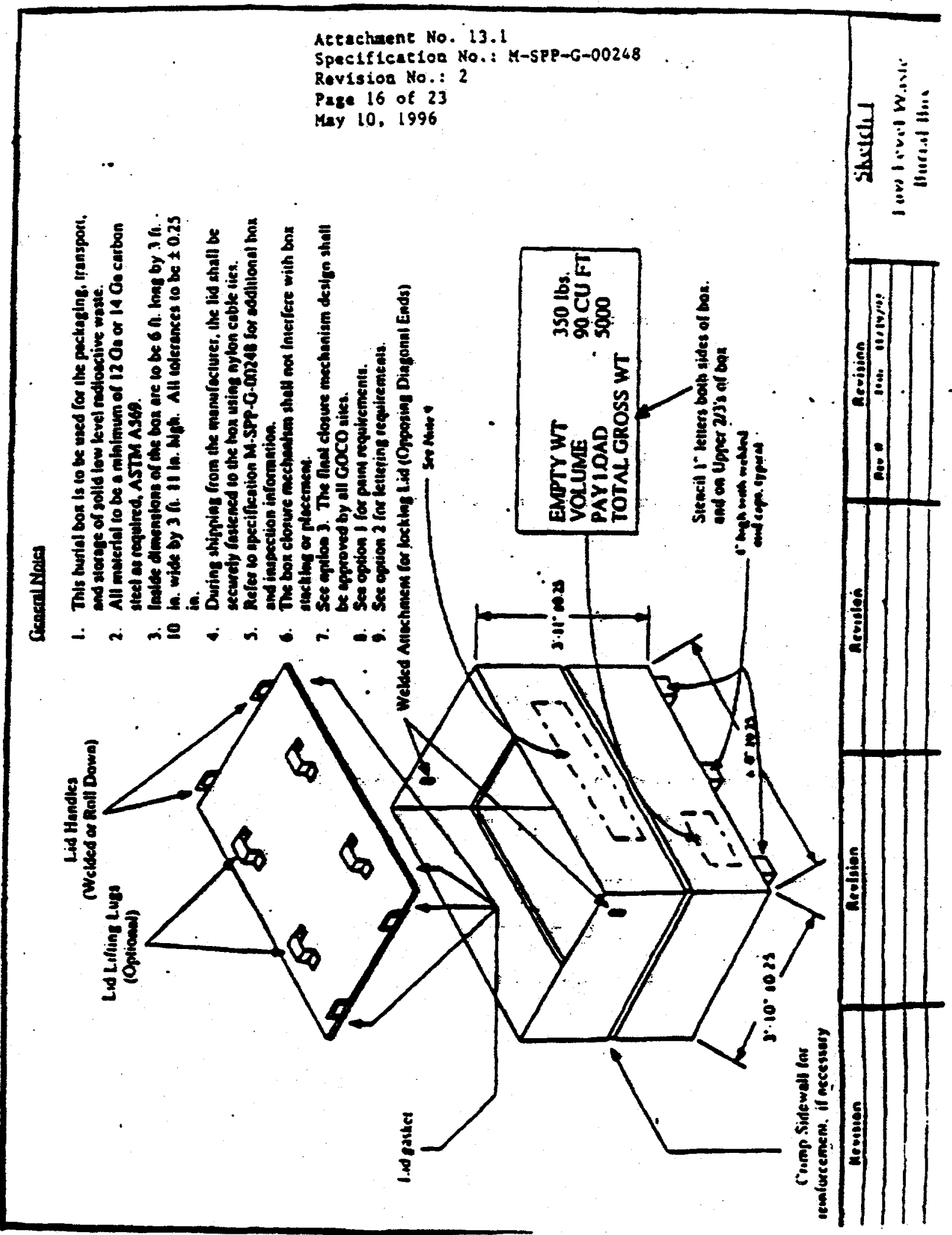




\section{Option 1}

Painting requirements:

1. No ancphosphate or equivalent primer used on interior or exterior surfaces of the box.

2. No zincphosphate or equivalent primer used on the interior surftes of the box. Zinc chromate grumar

- used on the exterior surtace of the box.

3. Zine phosphate or equivalent primes used on the interior and exterios surfaces of the box:

4. Paint the interior and exterior suffaces of the box usung an allyd enand finish.

5. Paint only the outside surface of the box with an alkyd enaend finish.

6. The final finish colors are as tollows:

White
- Black
- Yellow
Magenta

\section{Option 2}

\section{Lettertng Requrestentes:}

1. Stencil the following in one and onethalf inch (1.57) letters on ench sads of the bor

\section{DONOT PLAC HAZARDOUS WATERLIS RKUUDRG LEAD, CADMUR OR MERCURY WN THES BOX}

3. Do not wivel anything in this ared.

\section{Option 3}

Sealing Altarnatives for clesure of the contaner with the lid:

1. Banding.

2. Bolting.

3. Welding.

4. Tabs and wedges which are tack welded. 
WSRC-TR-98-i)()() $\leq 0$

Attachment 9 (Continued)

Revision 0

February 10. 1998

Page 46 of 55

Procupiment Spesifieation for Low Level Waste Box
Attachment No. 13.2

Specificanon No.: M-STR-G-00248

Revision No.: 2

Page 18 of 23

Date: May 10, 1996

\section{Option 4}

\section{DOT Type 7 A Container}

. Codes and Regulations:

In addition to the codes and regulations listed in section 3.1 of this specifucation. the following codes and regulanons will apply to DOT Type $7 A$ containers:

- Code of Federal Regulations. Tith 49 CFR 173.412, Additional Design Requirements for Type A Packaging 1990 revision.

Code of Federal Regulabons, tille 49 CFR 173.415(0). Authoriend Iype A Packaging, 1990 revision.

Code of Federal Regulations, Title 49 CFR 173.461. Demonstration of Complinese with Test, 1990 revision.

Code of Federal Regulations, Tite 49 CFR 173. 462, Imparation of Spermen for Testung. 1990 revision.

Code of Fedecal Regulations , Till 49 CFR 173.463, Packagung and Shiclding Testeng for Interity, 1990 revision.

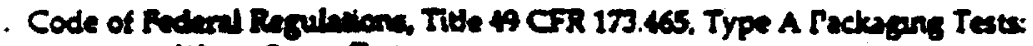
Wansores Tet

Pun Dup Tht

- Companionter

. Penetention trat

. Code of Federal Regulition, Title 49 CFR 178.350. Specification 7A. General Packagne Type A. 1990 revision.

\section{Testing:}

In addtion to the tests listed in section 7.2 of this spectication, the following tests will apply to DOT Type $7 \mathrm{~A}$ containers:

. The supplier will be requind to perfocm at least one Free Drop text por box deaign using Code of Federal Regulations. Title 49 CFR 173.465. Type A Pactageng Test. The test has to be parforsed with all five waste forme. 

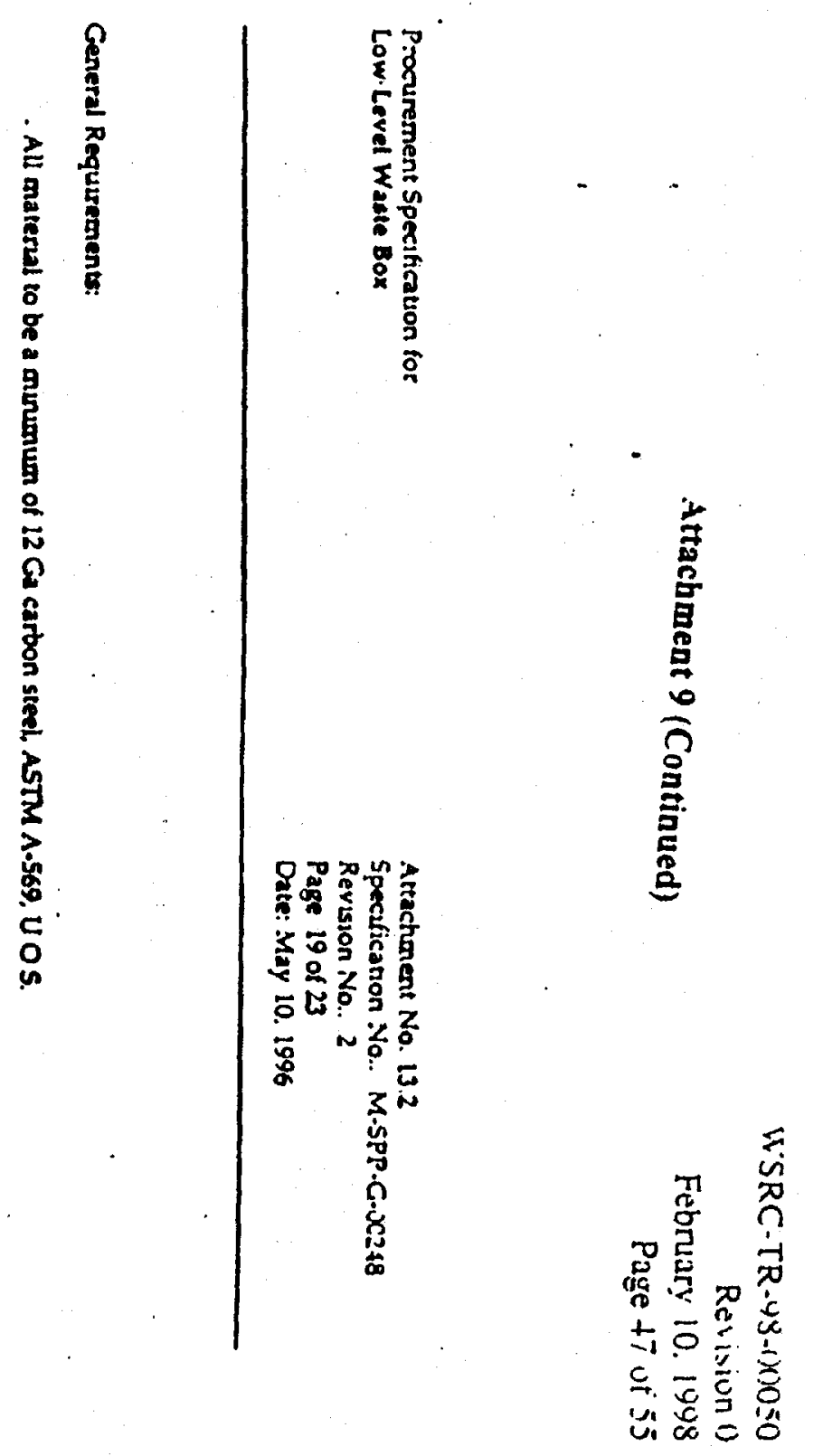
Procurement Specticanon for Low Level Waste Box
Atrachment No. 133

Specification No.: M.SPP-G.00248

Revision No.. 2

Page 20 of 23

Date: May 10. 1996

\section{Low Level Waste Burial Box Load Test Report}

NOTE: THE VENDOR MAY USE AN EQUTVALENT FORM AS LONG AS THE MINTMLM INFORMATION SHOWN BELOW IS INCLUDED.

Manufacturng Supplier

Product Teoted

Purchase Ordes Number

Date Product Manufactured

Date of last Box Load Test

Date of this Box Load Test

\section{IestRequinenenx}

NOTE: The suppliers procedure for box unifom land teing ause be nriewed and approved for ues by III coco.

The supplies shall perform at lecist one box load ters for each desifor of manufactured Low Level Waste Bural Boxes. The test shall derronstrate that a box that is half full of sand of water is capable of supportung a unsform lasd of twenty-two thousind pounds $(22.000 \div 300 \mathrm{bs}$ ) on the rop surface (lid) for a minimum of four hours (4) hes $\$ 5$ min.) with less than thre-eighths inch $(0.325 \div 0.1257$ deformation.

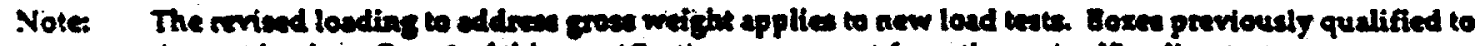
the net lasd per Rev. I of this specification are exempt from the revind londing test.

\section{Teres}

Lespis:

TerR-uin/Conmon

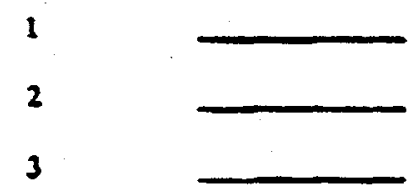

I certify that all boxes were in eccondance with the above described het and an approved Coco frocedurs and that the test sanple pased the test in all sespects.

Vendor QA inepecto

ICQR or COCO REP Witnessed
Dese

$$
\text { Date }
$$




\section{Low Level Waste Burial Box Box/Lid Seal Test Report}

NOTE: THE VENDOR MAY LSE AN EQUTVALENT FORM AS LONG AS THE MANIMUM INTORMATION SHOWN BELOW IS INCLUDED.

-Manufacturing Supplier

Product Teitud

Purchase Order Number

Date Product Manufactured

Date of last Box Land Teat

Date of the Box Load Test

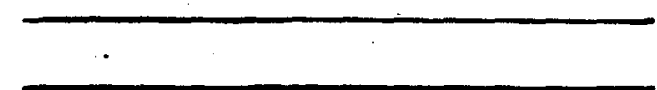

NOTE: The euppliar's procedire for boxhld senl feating wiunt be reviewed and approved for use by all coco.

The supplier shall perform at least one box/lid sed teat for each deaien of manufacturnd Low Level Waste Bural Boxes. The test shall demonstrate the effestivenus of the lid gashet sealing capability. Gasket compression of a minimum tweanty pescem shall be achieved.

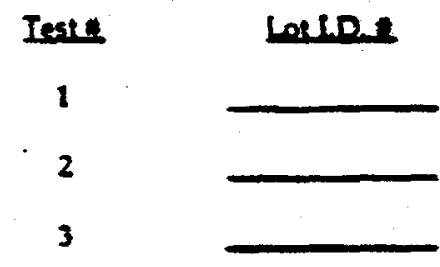

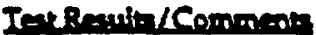

I certify that all boxes tested were in sccordance with the above described teat and an approved COCO Procedure and that the test sample passed the test in all respects.

Vendor QA inspector

Oats 
Procurement Specifieamon for Low Level Waste Box
Attachment No. 13.5

Specificaution No.: M.SPP.C-00245

Revision Nio.. 2

Page 22 of 23

Date: May 10. 1996

\section{Low Level Waste Burial Box Hydrostatic pressure/Leakage Test Report}

NOTE: THE VENDOR MAY USE AN EQUTVALENT FORM AS LONG AS THE MANEMUM INFORMATION SHOWN BELOW IS LNCLUDED.

Manufacturing Supplex

Product Tested

Purchase Order Number

Date Product Manufactured

Date of last Hydro/Leak Test

Date of this Hydro/Leak Test.

NOTE: The supplier's procedese for box leskage teating must be reviewed and approved for use by all coca.

The supplier shall cake a random sampla of five percent (5\%) of the boxes from each lot of Love Level Waste Burial Boxes, ananufactured and wea for water leakage. The box shall be filled to within one inch (1") from the top of the box with water and allow it to stand for four hours (4 he $15 \mathrm{~min}$ ). At the end of thes perriod, check the box for leaks. If any leaks are found then perform this leak teat on ten parcent (10\%) of the boxes troen that lot of boxes manufacturved. $Z$ any lake are found, then teat 100\% of the lot. Any leaking bones shall be ropared and re-tested by the mupplie as no cont to coco.

Teste
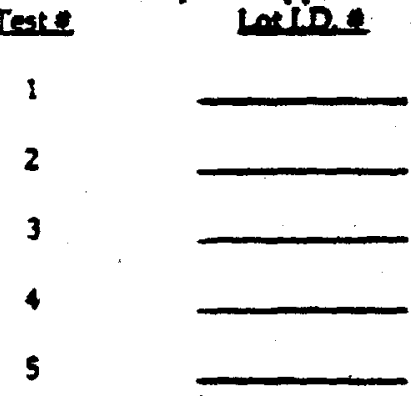

TenR-untakcomonom

I certify that all boxes tested were in eceordahce with the above detrribed wat and an approved GOCOProcedure and that the test sample passed the sest in all respects.

Vendor QA inspector

Date

ICQR or COCO REP Witrmesed

Date 
WSRC-TR-98-(1001) 50

Revision 0

- Attachment 9 (Continued)

February 10.1998

Puge 51 of 55

Procurement Specification for Low Level Waste Box
Attachment No. 13.6

Specificaton No.: M-SPP.G-D0248

Revsson No.: 2

Page 23 of 23

Date: May :0. :996

\section{Receiving Instructions for Inspecting the Low Level Waste Burial Box}

\section{EURPOSF}

These instructions ire to be used in conducting and documenting the recespt inspection required by WSRC QAP 7.2, when a shipment of Low Level Waste Bustal Boxes ane neceived. NOTE:All rresived contrinen in labeingesting

\section{RESPONSIITHTY}

The materuals coordinator for the receiving departnent/division or his delegate will be responsible for this inspection.

\section{INSPECOON PROCADURS}

1. Record the purchses order number, on nelease numbes, and unique identification numbers and the receiving date for this shipment. ID 1 's AX/KX

Date

2. Verify that the number of boxes in the shipment agees with the number of boxes shipped per the shipping papers.

$$
\text { Initial }
$$

3. Verfy that no boxes are danaged to the extent that the integrity or usefulnein of the box is compromised. As a guide, dents less then one-half inch $\left(0.5^{\circ}\right)$ and small scratches less than one square inch (1 in ${ }^{2}$ ) of expoced oneal nay be accepted. If damase causes suepieson that the lid whll not seal or that the box cantainonent is affectud, the box shall be njected, segregated and taged ("Do Not Operate"), and an NCR strall be writien.

4. Verify that the box has a lid

$$
\text { Initial }
$$

Initial

5. Verify that the vendor's inspection documentation, signed by the ICQR or COCO REP. has been received for thie shipentat.

\section{Initial}

6. Initiate a non conformance repont (NCR) for any box which does not pase ehis inspection. Send a copy of the NCR to the Departunent/Division material cusrodian responable for waste box procurement. Record dats: Number of boxes inspectud:

ID number of failed box(e) NCR Numbar:

7. Send a copy of thus document to the department/division material custodiun. Initial 


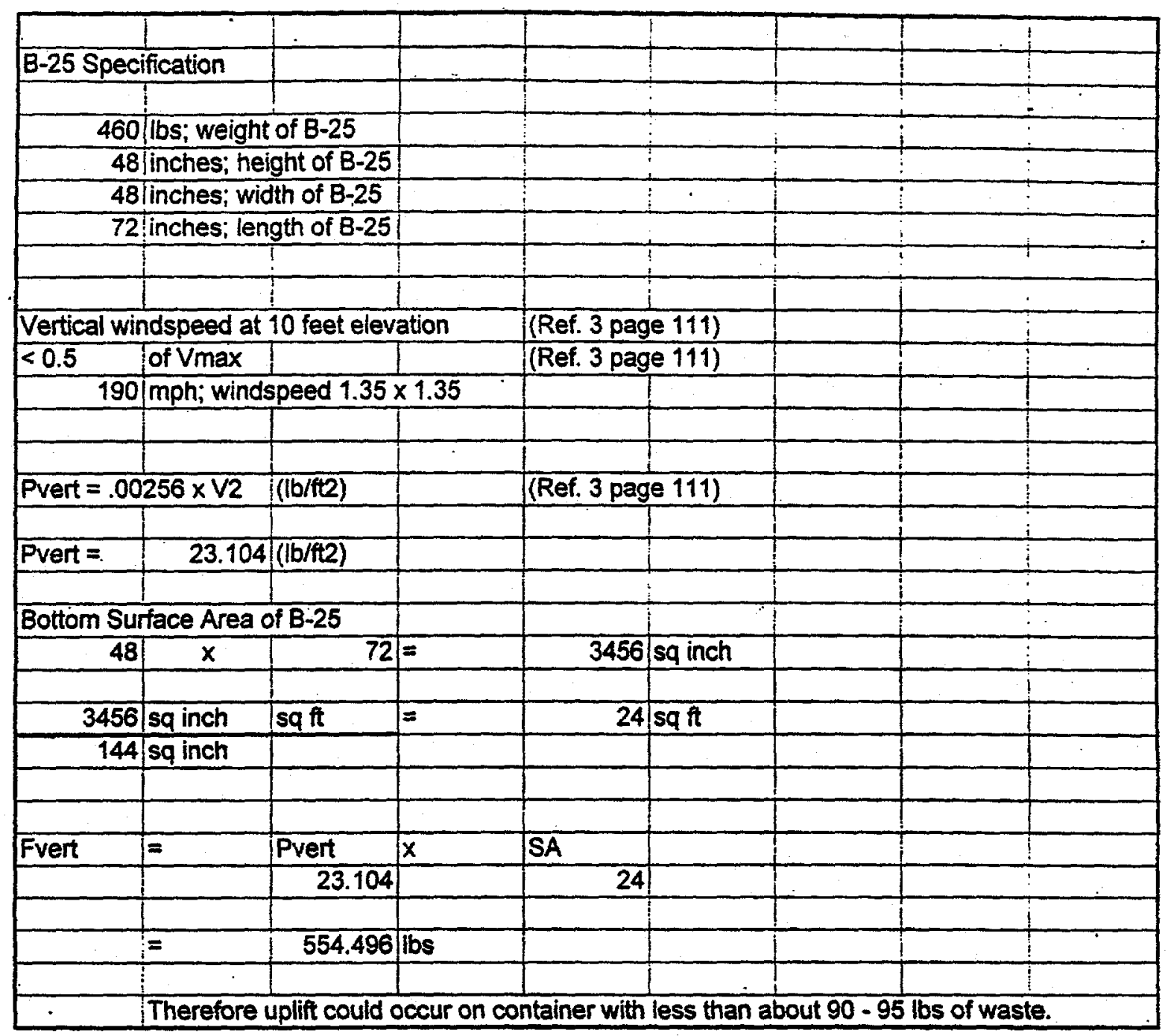


$\omega s e c-7 k-98-00050$

Attachment 11 - Max weight, TRU Loading

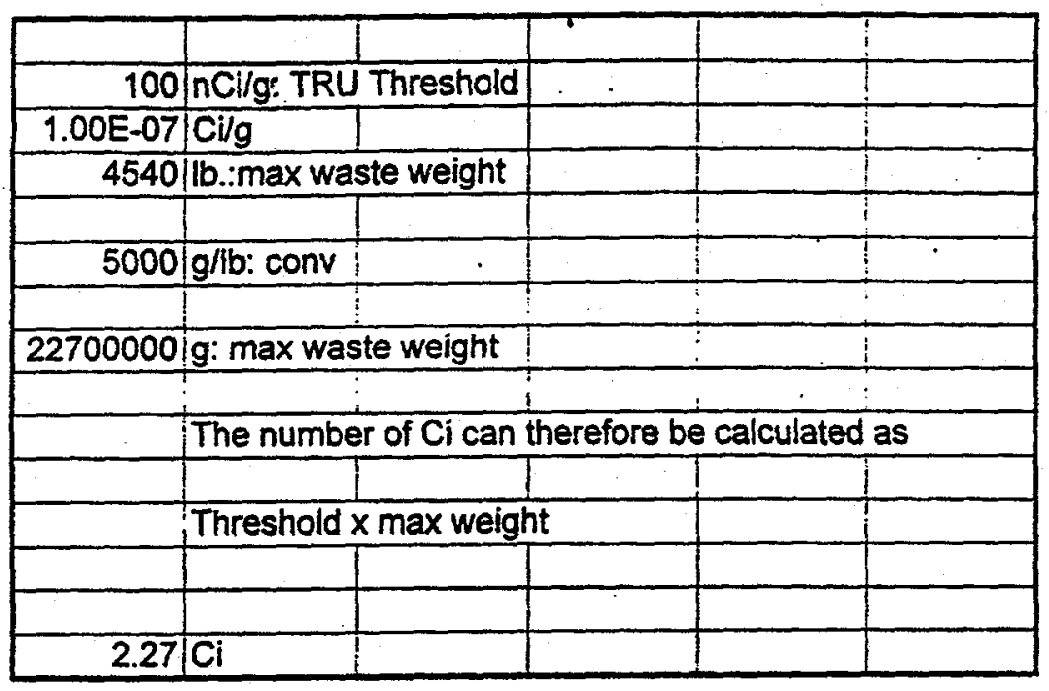

Page 53 
WSRC-TR-98-00050

Revision 0

February 10. 1998

Page it ot 55

This Page Intentionally Left Blank 
WSRC-TR-98-0000 50

Revision 0

February 10. 1948

Page 55 of 5

This Page Intentionally Left Blank 